\title{
La ordenación del turismo rural en Andalucía*
}

\author{
Severiano Fernández Ramos \\ Profesor Titular de Derecho Administrativo. \\ Universidad de Cádiz.
}

\begin{abstract}
SUMARIO: I. ASPECTOS GENERALES. 1. Introducción. 2. Los fundamentos de la política publica en materia de Turismo Rural. 3. La ordenación legal del Turismo Rural en España y en Andalucía en particular. II. EL CONCEPTO DE MEDIO RURAL Y REGLAS GENERALES. 1. El concepto de medio rural. 2. Reglas generales. III. EL ALOJAMIENTO TURÍSTICO EN EL MEDIO RURAL. 1. Los alojamientos específicos del turismo rural. 2. La noción de Casa Rural. 3. Especial referencia al ordenamiento andaluz. 4. Modalidades de prestación del servicio de alojamiento. 5. Requisitos de los establecimientos de alojamiento de turismo rural. 6. Condiciones generales de prestación de los servicios. 7. Régimen administrativo. 8. Otras modalidades de establecimientos alojativos rurales. IV. LAS ACTIVIDADES Y SERVICIOS TURÍSTICOS COMPLEMENTARIOS. 1. Los Establecimientos de Restauración. 2. La comercialización de los servicios turísticos rurales: las centrales de reservas. 3. Las medidas de promoción y fomento del turismo rural. V. CONCLUSIONES.
\end{abstract}

\section{ASPECTOS GENERALES}

\subsection{Introducción}

Si entendemos inicialmente por Turismo Rural la actividad turística que se desarrolla en el medio rural, constituye ésta una modalidad de turismo o "producto turístico" -en terminología empresarial ${ }^{1}$ - en alza constante, que se presenta cada vez más como complemento al turismo tradicional de "sol y playa”2. Para ello el turismo rural cuenta inicialmente con diversos atractivos, ta-

\footnotetext{
*A Pablo y Fuencisla, empresarios ejemplares de turismo rural.

${ }^{1}$ Así se expresa alguna norma, como la exposición de motivos del Decreto 67/1997 del Gobierno de Aragón sobre viviendas de turismo rural.

2 Según el informe de coyuntura correspondiente al 2003 de la Mesa del Turismo -http://www.mesadelturismo.com/-, el turismo rural prosigue un ritmo ascendente en España,
} 
les como el representar una huida de la masificación propia de las zonas urbanas, un regreso del ciudadano al medio rural y su reencuentro con la naturaleza, el acceso al patrimonio y a los bienes culturales en su más amplia acepción (comprensiva no sólo de los bienes materiales -patrimonio arquitectónico, arqueológico, museístico...- sino también de los bienes inmateriales -como los etnológicos, folclore, tradiciones, artesanía, gastronomía...) que aún se conservan en dicho medio, así como un trato más personalizado en los establecimientos alojativos y de restauración, a la vez que se ofrece al turista la posibilidad de efectuar un turismo más activo, menos alienante. Asimismo, precisamente por estas características, se trata de un producto demandado por un tipo de cliente de cierto nivel cultural y poder adquisitivo ${ }^{3}$.

Y estas razones que explican el auge de la demanda del Turismo Rural determinan, también, el interés creciente por parte de todas las Comunidades Autónomas en la promoción del Turismo Rural, en unos casos, como sucede en las regiones del interior (Aragón, Extremadura...), porque no existe otra alternativa de promoción turística, y en aquellas otras Comunidades que cuentan con litoral, como la andaluza, porque permite diversificar la oferta turística de la Comunidad Autónoma, de modo que no dependa exclusivamente del tradicional producto turístico de "sol y playa"4.

En efecto, el turismo de "sol y playa", además de estar condicionado por su estacionalidad, presenta unas características marcadamente homogéneas o

con un incremento de la demanda muy superior a la de la oferta alojativa de hoteles y apartamentos turísticos, pese a su menor peso cuantitativo. Entre enero y septiembre de 2003, el número de viajeros que reservaron sus vacaciones en casas rurales superó los 1,1 millones, con un aumento del $6,9 \%$ respecto del mismo período del 2002. Y por lo que respecta a las pernoctaciones, su incremento también fue notable, contabilizándose 3,57 millones de noches en alojamientos rurales durante los nueve primeros meses del año (un 8,8\% más que el mismo período del ejercicio precedente). De un modo más particularizado, el Patronato de Promoción y Turismo de Jaén estimó en el 2001 que el número de viajeros alojados había pasado de los 267.000 de 1992 a 500.000 en el 2000 (El País, 11.3.2001). No obstante, en el 2004 se observó en esta provincia un cierto descenso en la ocupación, que los propietarios de establecimientos de alojamiento rural achacaron al alto precio de la oferta complementaria, principalmente de restauración (El País, 12.9.2004).

${ }^{3}$ Como señala L. CORRALES BERMEJO, "Apuntes para la definición y concepto de Turismo Rural”, en Cuadernos de las Escuela Regional de Turismo De Castilla y León, Andanzas, 1, Ávila, 1993, p. 14, lo que distingue al turismo rural son sus características cualitativas. En este sentido, F.J. BLANCO HERRANZ, "Fundamentos de política comunitaria y española en materia de turismo rural”, Revista del Instituto de estudios turísticos, núm. 131, 1996, pp. 28-29.

${ }^{4}$ Así, J. TUDELA ARANDA, "Hacia el desarrollo de un concepto integral de turismo rural. Especial referencia a la Comunidad Autónoma de Aragón”, RArAP, núm. 19, 2001, p. 92, propone identificar la marca "Aragón" con el turismo rural. 
estandarizadas, que dificultan que cada país y, menos aún, cada Comunidad Autónoma, pueda individualizar un producto turístico propio de este tipo. Y esta circunstancia determina que el turismo de litoral esté particularmente sujeto a las tendencias actuales de globalización del mercado turístico y, por tanto, sometido a la competencia de productos similares entre distintas regiones y países, a lo cual debe unirse el fenómeno de la creciente dependencia de los productos turísticos de los grandes operadores del sector.

En cambio, frente a estas tendencias del sector turístico tradicional, debe subrayarse que el Turismo Rural permite su singularización como producto turístico con identidad propia y exclusiva, debido a las características antes referidas que determinan su esencial vinculación al medio, a sus recursos naturales y culturales. Así, es posible hablar, p. j., de un Turismo Rural Andaluz como producto turístico singularizado. En definitiva, un turismo rural de calidad puede constituir un factor esencial para la diversificación y cualificación de la oferta turística de un territorio.

\subsection{Los fundamentos de la política pública en materia de Turismo Rural}

Si cada vez se hace más evidente la necesidad de justificar en cada caso la intervención de los poderes públicos en el mercado, máxime en un sector económico casi exclusivamente privado, como es el turístico, son muchos y muy relevantes los intereses públicos que avalan la intervención activa del Derecho y de la Administración en el turismo rural.

En efecto, al margen de la importancia que tiene en sí misma la promoción de un sector económico en auge por lo que ello significa de generación de riqueza y de creación de empleo, sucede que el fomento del Turismo Rural presenta diversas virtualidades adicionales que justifican la atención de las Administraciones Públicas. De un lado, la promoción del Turismo Rural permite la diversificación económica del medio rural, pues al impulsar la oferta y prestación de servicios turísticos en el medio rural se crea un tejido empresarial que permite que las rentas del medio rural no dependan exclusivamente del sector primario agropecuario, sujeto tanto a la disponibilidad de recursos hídricos -en un país en el que el agua constituye un recurso escaso, en particular, en una región como la andaluza sometida a severos períodos de sequía-, como a los criterios y límites de producción fijados por la Política Agrícola Común de la Comunidad Europea, que frecuentemente impone o, al menos, promueve el abandono de explotaciones agrarias. De aquí el papel relevante que se está asignando al turismo rural en todas las políticas de Gobiernos autonómicos y locales en materia de desarrollo rural o local, en muchos casos 
con el apoyo financiero de la propia Unión Europea (en particular, desde la iniciativa comunitaria LEADER y el Programa Operativo PRODER). Asimismo, el desarrollo del turismo rural justifica e impulsa infraestructuras, fundamentalmente viarias, que de otro modo sería difícil que se llevaran a término, contribuyendo a una imprescindible política de equilibrio territorial ${ }^{5}$.

Y, de otro lado, a los objetivos económicos anteriores, debe añadirse que la promoción del turismo rural puede tener efectos positivos en orden a la recuperación y conservación del patrimonio cultural del medio rural -como es el caso de la rehabilitación de edificios o de caminos, calzadas, vías pecuarias y senderos rurales de especial valor-. Asimismo, el Turismo Rural puede constituir una vía de fomento de la sensibilidad ecológica, al permitir el acercamiento del ciudadano ("urbanita") a la naturaleza, y, sobre todo, al constituir una vía de generación de riqueza, el uso turístico de los espacios naturales protegidos constituye un importante argumento y recurso (sin derivar en un indeseable "monocultivo" turístico) para las políticas de protección y promoción de los mismos, frente a las habituales reservas de los habitantes de las comunidades rurales afectadas por la declaración de un espacio protegido ${ }^{6}$.

Asimismo, a nadie se le oculta que esta eclosión del sector turístico rural no está exenta también de riesgos, en especial si es desordenada, y que deben ser adecuadamente conjurados por las distintas Administraciones Públicas, y en particular los riesgos derivados del potencial impacto que pueden tener las actividades turísticas sobre el medio ambiente (degradación del paisaje), así como sobre los bienes culturales (la comercialización de acontecimientos culturales tradicionales puede dar lugar a una pseudocultura que amenace la calidad de la oferta). Y no debe olvidarse a este respecto la experiencia de décadas pasadas de desarrollo salvaje del turismo de litoral, con un deterioro y degeneración del medio difícil de reparar y perjudicial, a largo plazo, para la sostenibilidad del propio sector turístico. Además, la oferta de turismo rural presenta una cierta fragilidad, debida en gran medida al impacto de los recu-

\footnotetext{
${ }^{5} \mathrm{~J}$. TUDELA ARANDA, "Hacia el desarrollo de un concepto integral de turismo rural. Especial referencia a la Comunidad Autónoma de Aragón”, op. cit., pp. 75 y 77. De hecho, este autor considera que en Aragón, en particular, el turismo rural debe ser básicamente tratado como instrumento de equilibrio territorial y de desarrollo rural (p. 87).

${ }^{6}$ Vid., en este sentido, C. OLIMPIA SANZ SALLA, "Los sujetos del turismo: los establecimientos hoteleros y las empresas de alojamiento turístico de carácter no hotelero", en Lecciones de Derecho del Turismo, VV. AA., Tirant lo Blanch, Valencia, 2000, p. 110; J. TUDELA ARANDA, op. cit., pp. 65-66.
} 
rrentes incendios, frente los cuales es precisa una decidida política de prevención desde las Administraciones Públicas ${ }^{7}$.

Por último, las Administraciones Públicas deben velar por la protección de determinados intereses públicos, como la salud e integridad física de los usuarios turísticos -en particular en relación con la práctica de deportes de cierto riesgo-, y, en general, por los intereses económicos de los turistas, como usuarios finales de servicios. Más aún, las Administraciones competentes están compelidas a velar por la calidad de los servicios turísticos con objeto de salvaguardar la imagen misma del producto de marca, así como por el hecho innegable de que la calidad de la oferta es hoy en día un factor determinante para la consolidación de la demanda ${ }^{8}$.

Por todas estas razones, en relación con el turismo rural no son aplicables los criterios restrictivos generales sobre la intervención pública, sino que las políticas públicas, las normas y acciones en las que éstas se plasman, están llamadas a velar por los múltiples y relevantes intereses públicos sobre los que incide el desarrollo del turismo rural ${ }^{9}$.

\subsection{La ordenación legal del Turismo Rural en España y en Andalucía en par- ticular}

Desde el punto de vista competencial, al constituir el Turismo Rural una modalidad o sector específico de la actividad turística, está sujeto al reparto competencial propio del turismo como "materia competencial", y que -como es sabido- es considerada -con importantes matizaciones- como una compe-

\footnotetext{
${ }^{7}$ Los pavorosos incendios acaecidos en el verano del 2003 en la comarca extremeña de Las Hurdes tuvieron un impacto casi letal en el incipiente tejido industrial turístico de la zona. Aunque con menor gravedad, tras el verano de 2004, el Consejo Empresarial de Turismo de la Confederación de Empresarios de Andalucía presentó un balance de resultados destacando el daño que los incendios forestales causaron en el desarrollo turístico de las provincias de Jaén y Huelva.

${ }^{8}$ Como señala , J. TUDELA ARANDA, op. cit., 94, en materia de turismo debe interiorizarse la política de satisfacción del cliente, como algo mucho más exigente que una simple política de protección de los consumidores y usuarios. Asimismo, el fomento y asentamiento de turismo de calidad es objetivo prioritario omnipresente en las normas del sector: p. j., la exposición de motivos del Decreto de Extremadura 120/1998, de 6 de octubre, por el que se aprueba la ordenación del alojamiento en el medio rural.

${ }^{9}$ En este sentido, J. TUDELA ARANDA, "Hacia el desarrollo de un concepto integral de turismo rural", op. cit., p. 99.
} 
tencia exclusiva de las Comunidades Autónomas ${ }^{10}$, si bien no debe olvidarse que en la ordenación del turismo rural inciden múltiples títulos competenciales como la agricultura, el medio ambiente, el patrimonio cultural o la ordenación del territorio, entre otros- ${ }^{11}$.

En todo caso, no existe en la actualidad una normativa uniforme en el Estado español sobre el Turismo Rural, sino que la ordenación vigente se encuentra fraccionada en normas de las distintas Comunidades Autónomas, cuyos criterios, como es previsible, no siempre coinciden, de tal modo que una misma expresión, como es el turismo rural, cobija realidades dispares ${ }^{12}$. Y esta diversidad normativa entre las distintas Comunidades Autónomas en el tratamiento del Turismo Rural no deja de tener relevancia si se tiene presente que el Turismo Rural de cada Comunidad Autónoma es, desde el punto de vista económico, un producto turístico que deberá competir en el mercado con productos similares de otras Comunidades Autónomas. Al mismo tiempo, la heterogeneidad del producto de turismo rural presenta inconvenientes innegables, como la confusión del turista y la dificultad para su comercialización exterior $^{13}$.

${ }^{10}$ Sobre los límites de la competencia exclusiva de las Comunidades Autónomas en materia de turismo, vid. R. GARCÍA MACHO, "La legislación turística: naturaleza jurídica; relaciones entre Derecho estatal, autonómico y local", en Lecciones de Derecho del Turismo, VV. AA., Tirant lo Blanch, Valencia, 2000, pp. 25 y ss.; A. SALGADO CASTRO, "La distribución de competencias en materia de Turismo", Revista Aragonesa de Administración Pública, núm. 9, 1996, pp. 319 y ss; R. PÉREZ GUERRA, R. y M.M. CEBALLOS MARTIN, "A vueltas con el régimen jurídico-administrativo de la distribución de competencias en materia de Turismo y de otros títulos que inciden directamente sobre el mismo: El ejercicio de competencias turísticas por la Comunidad Autónoma Andaluza", Rev. Andaluza de Administración Pública, núm. 27, 1996; Mํạ. JAIMEZ GAGO, Políticas públicas y turismo, Consejería de Turismo, Comercio y Deporte, Sevilla, 2004, pp. 275 y ss.

${ }^{11}$ Vid. C. SANZ DOMÍNGUEZ, Régimen jurídico del turismo en el espacio rural: análisis y compendio normativo, Vol. II, Junta de Andalucía, 2002, pp. 59 y ss.

12 Sobre los escasos antecedentes normativos en la legislación estatal, vid. D. BLANQUER, "Régimen jurídico del turismo rural", Régimen Jurídico de los recursos turísticos, RArAP, 1999, pp. 441 y ss.

${ }^{13}$ Así lo ha señalado F.J. MELGOSA ARCOS, "Turismo rural y turismo activo", en Estudios de Derecho y Gestión Ambiental, I, Diputación Provincial, Ávila, 1999, p. 486. Téngase presente que, según la encuesta de ocupación en alojamientos de turismo rural (EOTR) correspondiente al mes de marzo de 2005 del Instituto de Estudios Turísticos de la Administración del Estado, el 86,4\% de las pernoctaciones fueron efectuadas por españoles, de modo que el mercado exterior sigue siendo un reto pendiente. 
Desde un punto de vista formal, la ordenación autonómica del Turismo Rural se contiene en dos niveles normativos. En primer lugar, deben mencionarse a las Leyes autonómicas de ordenación del Turismo que se han ido promulgando desde mediados de la década de los 90 . A este respecto, la situación es muy desigual. Así, algunas Leyes autonómicas ordenadoras del turismo se limitan a mencionar a los establecimientos de alojamiento turístico rural entre las clases de empresas o establecimientos de alojamiento turístico ${ }^{14}$. En cambio, otras Leyes autonómicas contienen determinaciones concretas de interés, si bien limitadas a los establecimientos de alojamiento turístico ${ }^{15}$. Pero en ambos casos se trata de determinaciones fragmentarias, referidas exclusivamente a los establecimientos alojativos y necesitadas de un ulterior desarrollo reglamentario, al que la Leyes autonómicas se remiten expresa o tácitamente, si bien se aprecia una mayor atención a esta materia en las últimas leyes autonómicas de turismo ${ }^{16}$.

En segundo lugar, la ordenación más completa está contenida en las mencionadas disposiciones reglamentarias, y aquí pueden diferenciarse dos etapas. En una primera fase que comprendería la década de los años 80 y primeros de los 90, la regulación se limitó casi en exclusividad a la modalidad de agroturismo ${ }^{17}$. De este modo, la ordenación del turismo rural se configuraba como una actividad auxiliar o secundaria de las actividades agrarias. En cambio, en una segunda fase se hace evidente que el concepto de turismo rural es más amplio que el de agroturismo, de modo que la ordenación se independiza conceptual y económicamente del sector agrario, sin perjuicio de la complementariedad que pueda existir en el medio rural entre ambas actividades económicas.

\footnotetext{
${ }^{14}$ Es el caso de la Ley Comunidad Valencia 3/1998 de Turismo -art. 8-, Ley de Castilla-La Mancha 8/1999 de Ordenación del Turismo -art. 15-, Ley de Cantabria 5/1999 de Ordenación del Turismo -art. 15.1-, Ley de Canarias 7/1995 de Ordenación del Turismo -art. 32-.

${ }^{15}$ Es el caso de la Ley del País Vasco 6/1994 de Ordenación del Turismo -art. 25-, la Ley de Extremadura 2/1997 de Turismo -art. 20-, la Ley de Galicia 9/1997 de Ordenación y Promoción del Turismo -arts. 27 y 29-, la Ley de Castilla y León 10/1997 de Turismo -art. 26-, la Ley de la Región de Murcia 11/1997 de Turismo -art. 13-, la Ley de la Comunidad de Madrid 1/1999 -art. 29-, la Ley de Baleares 2/1999 General Turística -arts. 15 y ss-, la Ley de Andalucía 12/1999 de Turismo -arts. 41 y $44-$.

${ }^{16}$ Ley de Cataluña 13/2002 de Turismo -arts. 49 y 50- y Ley de Aragón 6/2003 -arts. 41 a 43-.

${ }^{17}$ P. j., Decreto del País Vasco 295/1988, de 8 de noviembre, de establecimientos de agroturismo; Decreto de Aragón 113/1986, de 14 de noviembre, de Viviendas de Turismo Rural.
} 
Con todo, las regulaciones reglamentarias se suelen limitar aún a la ordenación de las modalidades específicas de alojamiento en el medio rural ${ }^{18}$. Este era el caso, entre otros, del ordenamiento andaluz, con el Decreto de 94/1995, de 4 de abril, de ordenación de los alojamientos en Casas Rurales andaluzas.

Ahora bien, es evidente que el turismo rural no se circunscribe exclusivamente a la actividad alojativa, sino que alcanza también una serie de servicios y actividades conexos o complementarios especialmente relacionados con el entorno rural ${ }^{19}$. En este sentido, se empieza apreciar una tendencia normativa a ordenar el turismo rural en su globalidad -establecimientos de restauración, intermediación, servicios complementarios... -, de la que es exponente el Decreto del Gobierno andaluz 20/2002, de 29 de enero, de Turismo en el

${ }^{18}$ Aragón: Decreto 84/1995, de 25 de abril, de ordenación de albergues y refugios; Decreto 69/1997, de 27 de mayo, de ordenación de las Viviendas de Turismo Rural; Asturias: Decreto 26/1991, de 20 de febrero, por el que se crea y regula la modalidad de alojamiento denominado "Casas de Aldea" y Decreto 69/1994, de 1 de septiembre, que aprueba la utilización de la marca "Casonas Asturianas", desarrollado por Resolución de la Consejería de Industria de 12 mayo de 2000, sobre Reglamento de uso de la marca "Casonas Asturianas"; Baleares: Decreto 62/1995, de 2 de junio, de prestación de servicios turísticos en el medio rural, desarrollada por Orden de 13 de octubre de 1995; Canarias: Decreto 18/1998, de 5 de marzo, de ordenación de los establecimientos de alojamiento de turismo rural, modificado por Decreto 39/2000, de 15 de marzo; Cantabria: Decreto 31/1997, de 23 de abril, de alojamientos y actividades turísticas en el medio rural; Castilla-La Mancha: Decreto 43/1994, de 16 de junio, de ordenación de los alojamientos en casas rurales; Castilla y León: Decreto 84/1995, de 11 de mayo, de ordenación de alojamientos de turismo rural; Cataluña: Decreto 214/1995, de 27 de junio, de ordenación de las Residencias-Casas de Pagés; Comunidad Valenciana: Decreto 253/1994, de 7 de diciembre, regulador del alojamiento turístico rural, modificado por Decreto 207/1999, de 9 de noviembre; Extremadura: Decreto 120/1998, de 6 de octubre, de ordenación del alojamiento en el medio rural; Galicia: Orden de 2 de enero de 1995, sobre ordenación de establecimientos de turismo rural, modificada por Orden de 7 de mayo de 1996, y finalmente sustituida por Decreto 191/2004, de 29 de julio, de establecimientos de turismo rural; La Rioja: Decreto de La Rioja 26/2000, de 19 de mayo, de ordenación de los alojamientos en casas rurales (que derogó al anterior Decreto 8/1995, de 2 de marzo), Decreto 41/1993, de 5 de agosto, de regulación de los alojamientos turísticos en zonas de adecuación naturalística, Decreto 11/1994, de 24 de febrero, sobre regulación y ordenación de alojamientos en posadas); Murcia: Decreto 79/1992, de 10 de septiembre, de regulación de los alojamientos especiales en zonas de interior; Navarra: Decreto Foral 105/1993, de 20 de marzo, de reglamentación de las casas rurales, modificado por Decreto Foral 53/1995, de 20 de febrero; País Vasco: Decreto 128/1996, de 28 de mayo, de regulación de los establecimientos de alojamiento turístico en el medio rural, modificado por Decreto 210/1997, de 23 de septiembre. Vid. el compendio normativo contenido en C. SANZ DOMÍNGUEZ, op. cit., vol II.

${ }^{19}$ Esta noción integral de turismo rural ha sido defendida por J. TUDELA ARANDA, "Hacia el desarrollo de un concepto integral de turismo rural", op. cit., p. 70. 
Medio Rural y Turismo Activo, y que derogó al mencionado Decreto de $94 / 1995^{20}$. No obstante, tal como se indicará más adelante, si bien el Decreto 20/2002 avanza en la concepción integral de los servicios turísticos en el medio rural, mantiene un enfoque unidimensional del turismo rural, pues, salvo referencias perfectamente retóricas, están ausentes en la norma la dimensión natural y cultural del turismo rural ${ }^{21}$.

\section{EL CONCEPTO DE MEDIO RURAL Y REGLAS GENERALES}

\subsection{El concepto de medio rural}

A diferencia de otras modalidades o sectores turísticos -como el deportivo o el social-, el turismo rural se caracteriza por su desarrollo en un espacio físico determinado, referido comúnmente como "medio rural", de aquí que algunos autores prefieran utilizar la expresión de "turismo en el espacio rural" ${ }^{22}$. Pero si la realidad a la que trata de referirse esta expresión puede ser fácilmente intuida, a la hora de concretar el concepto entran consideraciones que no dejan de ser convencionales. A este respecto, el Decreto J.A. de 94/1995 de Casas Rurales entendió por medio rural el espacio donde se desarrollan las actividades típicamente agrícolas, forestales, extractivas, pesqueras y ganaderas. De este modo, se vinculaba la noción de medio rural a las explotaciones agropecuarias y similares, restringiendo notablemente el ámbito territorial y funcional del turismo rural.

\footnotetext{
${ }^{20}$ Más aún, este Decreto 20/2002 no sólo ordena el turismo rural, sino que -como su propia denominación da a entender- regula también el llamado turismo activo. No obstante, ambas modalidades poseen rasgos claramente distintivos, pues -tal como admite la propia exposición de motivos del Decreto- el turismo rural constituye un turismo genérico, mientras que el segundo es un turismo específico, y no tiene por qué realizarse exclusivamente en el medio rural. Por estas razones, en este breve estudio nos limitamos a analizar las disposiciones relativas al turismo rural propiamente dicho, pues el turismo activo presenta una problemática propia. Por lo demás, el Decreto 20/2002 tiene su origen en el Plan Senda, de Desarrollo de un sistema turístico sostenible y competitivo integrado en el espacio rural andaluz, Dirección General de Planificación Turística, Consejería de Turismo y Deporte, Sevilla, 2000.

${ }^{21}$ Vid. D. BLANQUER, "Régimen jurídico del turismo rural", Régimen Jurídico de los recursos turísticos, RArAP, 1999, p. 449.

${ }^{22}$ Así, G.E. PALACIO Y DE MONTEMAYOR, "Régimen jurídico del turismo rural", RArAp, núm. 14, 1999, p. 630; C. SAINZ DOMÍNGUEZ, Régimen jurídico del turismo en el espacio rural, Vol. I, op. cit., p. 33.
} 
En cambio, el Decreto 20/2002 -art. 3-utiliza dos criterios complementarios: uno positivo y otro negativo. Desde el punto de vista positivo, el Decreto 20/2002 -art. 3.1- entiende por medio rural aquel en el que "predominantemente" se desarrollan actividades agrícolas, forestales, pesqueras de carácter fluvial y ganaderas, de modo que la vinculación a este tipo de actividades ya no es exclusiva ${ }^{23}$. Y, desde un punto de vista negativo, el Decreto 20/2002 -art. 3.2- declara expresamente excluidos de la consideración de medio rural determinados espacios, pudiéndose diferenciar dos exclusiones básicas y otras adicionales o complementarias. Sin embargo, antes de analizar estas exclusiones, puede avanzarse que el cambio de perspectiva adoptado es mayor de lo que parece a primera vista, pues, en realidad, a pesar de que se siga formalmente haciendo referencia positiva a las actividades agrarias, el elemento determinante en la práctica será, previsiblemente, que la zona no se encuentre dentro de alguna de las exclusiones que siguen.

\subsubsection{Exclusiones básicas: el turismo rural no es turismo de litoral ni de ciudad.}

El Turismo rural es evidentemente una modalidad de turismo de interior, en oposición al turismo de litoral ${ }^{24}$. Sin embargo, a la hora de precisar esta distinción se aprecian criterios diversos en los distintos ordenamientos autonómicos. En algún caso se excluyen, de un modo global, a todos los municipios que cuenten con término municipal limítrofe con el $\operatorname{mar}^{25}$, mientras que en otros casos la exclusión es más matizada ${ }^{26}$.

Por su parte, el Decreto 20/2002 excluye de la noción de medio rural a: "Los núcleos de población situados en el litoral andaluz". De este modo, el Decreto 20/2002 no parece excluir a todo municipio que cuente con costas o litoral en su término municipal, sino exclusivamente a aquella parte de dichos municipios que denomina "núcleos de población" ${ }^{27}$. No obstante, habría sido

${ }^{23}$ En este sentido, el Decreto 76/1989 de Castilla y León delimitaba el núcleo rural como asentamiento cuya economía sea principalmente, sin excluir otra, agrícola, ganadera, forestal o minera.

${ }^{24}$ En este sentido, el Plan General de Turismo de Andalucía, aprobado por Decreto 340/2003, de 9 de diciembre, en la relación entre turismo y territorio, diferencia entre un turismo de litoral, de ciudad y rural.

${ }^{25}$ Decreto de la Comunidad Valenciana 253/1994 -art. 2.2-.

26 Así, la Ley de Murcia 11/1997 -art. 22- exige que el establecimiento de alojamiento rural se sitúe fuera del litoral y de los cascos urbanos de los municipios costeros.

27 Ya la Orden de 22.12.2000 de la Consejería de Turismo y Deporte de la J. A, había anticipado este criterio a efectos de la concesión de subvenciones, al excluir de las mismas a los "nú- 
conveniente, para una mayor certidumbre jurídica, precisar qué se entiende, a estos efectos, por "núcleo de población" y por "litoral". Con todo, puede interpretarse que por "litoral" debe entenderse la Zona de Influencia del Litoral según la define el artículo 10.1 A) i) de la Ley 7/2002, de 17 de diciembre, de Ordenación Urbanística de Andalucía (en concordancia con el art. 30 de la Ley de Costas), esto es la que defina el PGOU y como mínimo quinientos metros a partir del límite interior de la ribera del $\operatorname{mar}^{28}$. No obstante, debe señalarse que se trata de un parámetro muy alejado del establecido en alguna otra Comunidad Autónoma ${ }^{29}$. Asimismo, de acuerdo con una interpretación sistemática, esta exclusión alcanzaría a todos los núcleos de población, aun cuando no excedan del límite de población fijado en la siguiente exclusión.

De otro lado, es evidente que no todo el turismo de interior debe considerarse turismo rural propiamente dicho, pues la referencia al medio rural parece comportar un turismo diferente del que ofrecen las ciudades (turismo urbano). Ciertamente cuál deba ser al número máximo de habitantes del Municipio o núcleo de población es un elemento convencional, en el que deberá tenerse presente la distinta conformación de los asentamientos en las diversas Comunidades Autónomas, si bien también se aprecia aquí una tendencia a la expansión de la noción de espacio rural ${ }^{30}$. En efecto, algunas Comunidades Autónomas requieren que el establecimiento esté emplazado en núcleos rurales pequeños, limitando el número de habitantes en cifras que oscilan de los

cleos de población" situados en el litoral andaluz. Piénsese, p. j., el caso en la provincia de Cádiz de Tarifa, con un importante turismo de litoral ligado a actividades acuáticas, pero con zonas de interior de carácter inequívocamente rural (como el área de Facinas).

${ }^{28}$ Esta interpretación parece avalada también por Decreto 164/2003, de 17 de junio, sobre campamentos de turismo, al definir la modalidad de campamento de turismo rural -art. 8.1-.

${ }^{29}$ Es el caso de la Región de Murcia, donde el Decreto 79/1992 -art. 4- entiende por litoral, a estos efectos, el espacio de 5 kilómetros tierra adentro, medido desde el límite externo de la zona de dominio público marítimo terrestre, es decir, un espacio diez veces mayor.

${ }^{30}$ Así pueden compararse además del caso andaluz, las sucesivas versiones de la normativa de Castilla y León plasmadas en los Decretos 76/1989, de 4 de mayo; 75/1992, de 7 de mayo, y 84/1995. Caso singular es el Decreto de Galicia 191/2004, de 29 de julio, de establecimientos de turismo rural, el cual no emplea criterio objetivo alguno, pues se limita a señalar que el espacio rural donde se asienten los establecimientos debe tener "las características propias de su entorno, un ambiente de tranquilidad, no estar afectado por estructuras urbanas degradadas, actividades minerales o extractivas superficiales y contar con vías de acceso adecuadas" -art. 1-. Sobre el relativismo de estas determinaciones legales, vid. D. BLANQUER, "Régimen jurídico del turismo rural”, Régimen Jurídico de los recursos turísticos, RArAP, 1999, pp. 456. 


\subsection{0 habitantes de Aragón, los 1.500 de La Rioja o los 3.000 de Navarra a los 10.000 habitantes de Castilla-La Mancha ${ }^{31}$.}

Pero, además, en general, la cifras de población no excluyen la posibilidad de calificar como medio rural a parte del término municipal de los municipios que las excedan en su conjunto, sino que se utilizan para excluir de la consideración de medio rural a los "núcleos de población", pero admitiendo la ubicación de establecimientos de turismo rural fuera de los mismos, en suelo no urbanizable ${ }^{32}$.

En el caso concreto de Andalucía, es notorio que los núcleos rurales presentan una media de población muy superior a la de otras Comunidades Autónomas ${ }^{33}$. Por su parte, el Decreto 20/2002 excluye de la noción de medio rural a: "Los núcleos de población que según el padrón actualizado excedan de 20.000 habitantes" 34 . De nuevo, debe observarse que el precepto no parece excluir a los Municipios en su totalidad, sino aquellos "núcleos de población"

31 Decreto del Gobierno de Aragón 69/1997 -art. 2.1-; Decreto La Rioja 26/2000 -art. 5-; Decreto Foral 243/1999 -art. 3-, si bien admite que se sitúe en una población mayor a una distancia superior a 200 metros del polígono de delimitación del suelo urbano y en una zona de construcción diseminada. Por su parte, la Ley de Aragón 6/2003, de Turismo, establece que los alojamientos de turismo rural deben ubicarse necesariamente en asentamientos tradicionales de población de menos de mil habitantes de derecho en el caso de las viviendas de turismo rural, o de menos de tres mil habitantes de derecho si se trata de hoteles rurales -art. 41.1-. Decreto de Castilla-La Mancha 43/1994 -art. 3-. Por su parte, el Decreto de Extremadura 120/1998 -art. 7- admite la ubicación de las casas rurales en localidades de menos de 5.000 habitantes de derecho, si bien en relación con los hoteles rurales admite la ubicación en localidades de hasta 10.000 habitantes siempre que se trate de edificios singulares -art. 43-.

${ }^{32}$ Así el Decreto del Gobierno de Aragón 69/1997 -art. 2.1- admite que pueda ubicarse en un núcleo con más de 1000 habitantes "cuando esté situada claramente fuera del caso urbano". De otro lado, el Decreto de Castilla y León 84/1995 -art. 5- exige la ubicación en una población de menos de 3.000 habitantes, si bien admite la ubicación en municipios de hasta 20.000 habitantes, siempre que la casa rural esté situada en suelo no urbanizable. Por su parte, Ley de Asturias 7/2001 -art. 37.2- combina dos criterios: los alojamientos de turismo rural habrán de ubicarse necesariamente en asentamientos tradicionales de menos de 500 habitantes, o en suelo no urbanizable, cualquiera que sea su calificación.

33 Así, cabe recordar que mientras la población media de los municipios de la Comunidad de Aragón es de 1.652 habitantes, en Andalucía asciende a 9.415 (datos de población del censo de 1996).

${ }^{34}$ Ya la mencionada Orden de 22.12.2000 de la Consejería de Turismo y Deporte de la J. A sobre subvenciones excluyó al núcleo principal de población de los municipios que, según el padrón municipal declarado oficial, excedieran de 20.000 habitantes. 
que excedan dicha cifra, lo cual puede plantear problemas de seguridad jurídica. Por ello hubiera sido interesante precisar que la noción cubre a aquellos núcleos que, aun perteneciendo a términos municipales de población superior a la indicada, se encuentran separados del caso urbano ${ }^{35}$. En todo caso, no puede dejar de señalarse que la cifra límite de 20.000 habitantes está muy por encima de lo que estima deseable por los profesionales del sector ${ }^{36}$.

\subsubsection{Exclusiones adicionales}

Además de los anteriores criterios, el Decreto 20/2002 contiene dos precisiones ulteriores:

De un lado, siguiendo el criterio de otras normas autonómicas ${ }^{37}$, el Decreto 20/2002 excluye "Las zonas de protección de las carreteras y sus áreas y zonas de servicio, según lo dispuesto en la Ley 8/2001, de 12 de julio, de Carreteras de Andalucía" ${ }^{8}$. Aun cuando es una determinación muy razonable para los establecimientos alojativos y, en este sentido, el posterior Decreto $47 / 2004$, de 10 de febrero, de establecimientos hoteleros, diferencia entre establecimientos hoteleros rurales -art. 34- y de carretera -art. 35-, la referencia a las zonas de servicio supone la exclusión de las típicas "ventas" de carretera, que aun cuando reúnan los requisitos del art. 20.2 no podrán obtener la calificación de mesón rural, salvo que se hago uso de la cláusula de excepción del art. 3.3.

De otro lado, el Decreto 20/2002 excluye: "Las zonas próximas a fábricas, industrias, vertederos, instalaciones o actividades incluidas en los Anexos I y II de la Ley 7/1994, de 18 de mayo, de Protección Ambiental, que provoquen efectos contaminantes, ruidos o molestias que afecten al turista", esto es las ac-

${ }^{35}$ Así se pronunciaba el Decreto de Castilla y León 75/1992, de 7 de mayo.

${ }^{36}$ El Ágora Internacional de Turismo Rural, celebrado en Jaén en octubre 2004, indicó que los establecimientos de turismo rural debía ubicarse en el campo o en aldeas sin que pudieran superar los 5.000 habitantes.

${ }^{37}$ El Decreto de la Comunidad Valenciana 253/1994 -art. 7.2- dispuso que las edificaciones no se encontrarán situadas al borde de carreteras nacionales o autonómicas de primer rango.

${ }^{38}$ De acuerdo con esta Ley 8/2001 -art. 53-, las zonas de protección de las carreteras son cuatro: la zona de dominio público adyacente -art. 12-, la zona de servidumbre legal -art. 54-, la zona de afección -art. 55-, y la zona de no edificación -art. 56-. Asimismo, las áreas y zonas de servicio de las carreteras están definidas en los arts. 13 y 14 de la Ley 8/2001, como elementos -públicos y privados, respectivamente- destinados a cubrir necesidades de la circulación viaria. 
tividades sometidas a las medidas de prevención ambiental de evaluación de impacto ambiental (Anexo I) y de informe ambiental (Anexo II) ${ }^{39}$. Y, en efecto, parece incompatible con la noción misma de turismo rural el emplazamiento en una zona de usos industriales o similares ${ }^{40}$. Lo que no se entiende bien es el añadido del precepto, según el cual ha de tratarse de instalaciones catalogadas "que provoquen efectos contaminantes, ruidos o molestias que afecten al turista", pues tales efectos son inherentes a todas y cada una de las actividades contenidas en los citados anexos de la Ley 7/1994. Asimismo, la referencia a "zonas próximas" no puede ser más vaga. Por ello el precepto prevé que por Orden de la Consejería de Turismo y Deporte se especificarán las distancias de tales zonas -parece inferirse que serán distintas según se trate de actividades de uno $\mathrm{u}$ otro Anexo- ${ }^{41}$.

Finalmente, el Decreto 20/2002 -art. 3.3- admite la posibilidad excepcional de declarar como espacio rural a determinados municipios o áreas integrados en alguno de los apartados anteriores ${ }^{42}$. La declaración, que -como es obligado- deberá ser motivada, podrá deberse, "entre otras causas, a su ubicación en un entorno especialmente pintoresco, o su relevante valor paisajístico o su dedicación a una actividad eminentemente artesanal". El Decreto prevé que esta declaración de espacio rural pueda adoptarse de oficio o a instancia de la entidad local afectada, pero curiosamente no contempla la posibilidad de que sea un particular interesado - p. j., en acogerse a las ayudas públicas- el que inicie el procedimiento. Por último, merece destacarse la intervención en este procedimiento del Consejo Andaluz de Turismo mediante informe preceptivo ${ }^{43}$.

39 Como precedente de esta norma puede citarse el Decreto de la Comunidad Valenciana 253/1994 -art. 7.2-, según el cual las edificaciones de casas rurales no se encontrarán situadas a una distancia inferior a un kilómetro respecto a vertederos u otros factores de contaminación ambiental. Lo cierto es que ni siquiera se garantiza la distancia de dos kilómetros que fijara el viejo Reglamento de Actividades Clasificadas -art. 4-.

40 Debe observarse que el Anexo II de la Ley 7/1994 de Protección Ambiental de Andalucía incluye las explotaciones ganaderas a partir de determinadas dimensiones (núm. 11).

41 Ahora bien, hasta tanto no se apruebe dicha Orden que fije las distancias mínimas, no será de aplicación esta exclusión del concepto de medio rural, según dispone la transitoria $7^{\mathrm{a}}$ del Decreto $20 / 2002$.

42 Estas cláusulas de exención están también presentes en otras normas autonómicas, como el Decreto de la Comunidad Valenciana 253/1994 -art. 2.3-.

43 Curiosamente se trata de una competencia no prevista en el Decreto 21/2002, de 29 de enero, por el que se regula la organización y funcionamiento del Consejo Andaluz de Turismo, por tanto de idéntica fecha que el Decreto 20/2002. 
En definitiva, el Decreto 20/2002 consagra una noción de espacio rural más amplia que la contenida en la norma anterior, y que permite englobar tanto zonas urbanas de municipios pequeños, como zonas de edificaciones aisladas en suelo no urbanizables, incluidos los espacios naturales protegidos que en la Comunidad Autónoma andaluza cubren, como es sabido, una importante extensión ${ }^{44}$.

\subsection{Reglas generales}

\subsubsection{Integración en el medio rural.}

El Decreto 20/2002 -art. 7.1- establece, de un modo un tanto retórico, que la prestación de los servicios turísticos se realizará respetando el medio y las características del espacio y de sus valores sociales y medioambientales, incluido el respeto a la fauna y flora silvestre y al paisaje natural. Y es cierto que no deben obviarse los potenciales efectos negativos sobre el medio ambiente de un desarrollo ordenado del turismo en el medio rural (generación de residuos y vertidos, perturbaciones a la fauna y flora, especulación del suelo...), puesto que los valores ambientales constituyen precisamente el principal recurso del turismo rural ${ }^{45}$. A este respecto, es evidente que el potencial impacto ambiental será muy diverso en función de la ubicación de los establecimientos turísticos en suelo urbano, no urbanizable ordinario, o en un espacio natural protegido. Y también será determinante el tipo de establecimiento turístico que se admita en el medio rural, debiendo observarse que la imposición legal de una oferta reducida (mediante límites a la capacidad alojativa de los establecimientos), unida a otras exigencias, determina una cierta dispersión de los turistas en el espacio rural, limitando los potenciales impactos negativos.

Por su parte, si los servicios turísticos se desarrollan en espacios naturales protegidos deberán ajustarse a los correspondientes instrumentos de protec-

\footnotetext{
${ }^{44}$ En este sentido, como señala el Plan General de Turismo de Andalucía, aprobado por Decreto $340 / 2003$, el hecho de que casi el $19 \%$ de la superficie regional está incluida en alguna figura de protección medioambiental supone una fuerte baza para el desarrollo en Andalucía del turismo ecológico. Tan sólo los Parques Naturales (el 91\% de la superficie total) suponen en Andalucía una superficie cercana al millón y medio de hectáreas, alrededor del 17\% de la superficie de la Comunidad Autónoma, dato que contrasta con el poco más del $7 \%$ del total en el conjunto de España. Vid. J. M. AYLLÓN DÍAZ-GONZÁLEZ, "Balance y perspectivas de la protección del medio natural en Andalucía", Rev. Andaluza de Administración Pública, número extraordinario 2/2003, volumen 2, p. 397.

${ }^{45}$ Vid. F.J. MELGOSA ARCOS, "Turismo, medio ambiente y desarrollo sostenible", en Estudios de Derecho y Gestión Ambiental, I, Diputación Provincial, Ávila, 1999, pp. 450 y ss.
} 
ción -básicamente Plan de Ordenación de Recursos Naturales y Plan de Uso y Gestión en el caso de los Parques Naturales-, los cuales suelen expresar la necesidad de promover la cooperación entre las Consejerías competentes en medio ambiente y turismo para garantizar el adecuado desarrollo de las actividades turísticas en estos espacios naturales. En general, estas normas, referidas fundamentalmente a parques naturales andaluces, coinciden en señalar las directrices siguientes ${ }^{46}$ :

a) El potencial turístico del Parque Natural debe entenderse como motor dinamizador y de diversificación de la economía de los municipios e instrumento para difundir la singularidad natural y cultural del espacio protegido.

b) La promoción del Parque Natural como reclamo turístico debe tener en cuenta la oferta la demanda existente así como el potencial de actividades de tipo turístico-recreativo.

c) La búsqueda del modelo turístico más adecuado ha de pasar por la implicación de la población local en el desarrollo y explotación de este recurso y ha de estar orientada por los principios siguientes: adoptar medidas que estimulen el desarrollo de un turismo consciente y responsable con el medio ambiente y con la población y cultura local; fomentar iniciativas que coadyuven a la conservación y mantenimiento de las actividades tradicionales; promover las iniciativas de origen autóctono; apoyar la implantación de una oferta turística de calidad compatible con los objetivos del Parque Natural; potenciar la diversificación de la oferta como respuesta a las nuevas demandas, en especial las de turismo activo; y fomentar la recuperación de construcciones con valor histórico y patrimonial.

Ahora bien, a pesar de las inevitables llamadas a la cooperación, lo cierto es que existen puntos de fricción entre las instituciones competentes en materia de turismo y de espacios naturales, derivados de la llamada "capacidad de carga" de los espacios naturales protegidos, que viene a constituir una importante limitación de los usos turísticos e, incluso, de las campañas de promoción ${ }^{47}$.

\footnotetext{
${ }^{46}$ P. ej., Decreto 57/2004, de 17 de febrero, por el que se aprueban el Plan de Ordenación de los Recursos Naturales y el Plan Rector de Uso y Gestión del Parque Natural Sierra Mágina; Decreto 79/2004, de 24 de febrero, por el que se aprueban el Plan de Ordenación de los Recursos Naturales y el Plan Rector de Uso y Gestión del Parque Natural Bahía de Cádiz; Decreto 87/2004, de 2 de marzo, por el que se aprueban el Plan de Ordenación de los Recursos Naturales y el Plan Rector de Uso y Gestión del Parque Natural Los Alcornocales.

47 Así, el propio Plan General de Turismo de Andalucía, aprobado por Decreto 340/2003, de 9 de diciembre, tras la consabida referencia a la necesidad de coordinación entre las Administra-
} 
Una de las principales fuentes de fricción viene determinada, como es lógico, por la demanda de suelo en el medio rural para las construcciones destinadas a usos turísticos. A este respecto, los instrumentos de ordenación de los espacios naturales suelen expresar la preferencia de emplazar las edificaciones vinculadas a actividades de turismo en suelo urbano, o en núcleos urbanos consolidados o áreas contiguas, definidos como tales por las normas urbanísticas correspondientes, favoreciendo así su conexión con los sistemas generales de abastecimiento y saneamiento. Sólo de manera excepcional se admite el emplazamiento en suelo no urbanizable cuando los servicios complementarios que ofrezcan los establecimientos imposibiliten su ubicación en suelo urbano. Y, en tal caso, en las declaraciones de interés público, previstas en la Ley $7 / 2002$, de 7 de diciembre, de Ordenación Urbanística, la protección ambiental deberá tener un valor preponderante entre los criterios de valoración social que permitan la construcción en suelo no urbanizable ${ }^{48}$. Más aún, debería extenderse el criterio establecido en alguna Ley autonómica de ordenar en estos casos de instalaciones turísticas en espacios naturales protegidos de un estudio básico de impacto ecológico ${ }^{49}$.

De otro lado, y con independencia de la ubicación del establecimiento turístico en un espacio natural protegido, debe observarse que algunas normas ambientales autonómicas ordenan algún mecanismo de intervención de la Administración competente en materia ambiental ${ }^{50}$. Lo cierto es que deberían impulsarse los instrumentos que permitan prevenir el impacto am-

ciones Ambiental y Turística, señala el grado de indefinición que existe sobre la noción misma de "capacidad de carga". Sobre la capacidad de carga, vid. L. CORRALES BERMEJO, op. cit., pp. 2021, donde se diferencia tres tipos: capacidad de carga física (determinada por los factores limitantes físicos, como el abastecimiento y evacuación de agua, capacidad de absorción de tráfico de las carreteras... ), capacidad de carga perceptual o psicológica (relación residentes/turistas) y capacidad de carga paisajística (potencialidad del entorno para absorber el uso recreativo, lo que dependerá de la fragilidad del medio).

\footnotetext{
${ }^{48}$ Véase, p. j., los Decretos ya citados de los Parques Naturales Sierra Mágina, Bahía de Cádiz y Los Alcornocales.

${ }^{49}$ Criterio de la Ley de Canarias 7/1995 del Turismo, la cual extiende este criterio a las áreas de sensibilidad ecológica -art. 27-.

${ }^{50}$ Es el caso de la Ley de Cataluña 3/1998 de Intervención Integral de la Administración Ambiental, la cual somete el régimen de licencia ambiental a los establecimientos de "hostalería" con un número de habitaciones superior a 50, y al régimen de comunicación previa a los establecimientos de "hostalería" con un número de habitaciones no superior a 50. De modo similar, Ley Foral 4/2005, de 22 de marzo, de intervención para la protección ambiental.
} 
biental de las actividades de turismo rural ${ }^{51}$. En definitiva, no debe olvidarse que la calidad de los recursos ambientales en sentido amplio -fundamentalmente del paisaje rural- es el principal el factor de atracción de esta modalidad turística ${ }^{52}$.

\subsubsection{Calidad del turismo rural.}

El Decreto 20/2002 establece -art. 8.1- que todo servicio y establecimiento turístico inscrito en el Registro deberá ser ofertado en las convenientes condiciones de uso, buscando la satisfacción de las expectativas del cliente y su integración el medio, conservando las instalaciones y servicios, al menos, con la calidad que fue tenida en cuenta al ser inscrito ${ }^{53}$. Para ello las normas ordenan una serie de determinaciones materiales de obligado cumplimiento en las que se traducen la calidad de los servicios turísticos, si bien, por lo general, tales exigencias se centran en las instalaciones, olvidando la necesidad de garantizar una cualificación profesional ${ }^{54}$. Asimismo, el respeto al estilo arquitectónico rural es también, en sí mismo, un factor de calidad, como también lo es la preocupación por la formación de los gestores y profesionales en materia turística. Además, en relación con la calidad de las prestaciones, equipamientos y servicios turísticos, la implantación de sistemas de distintivos de calidad constituye un importante factor de transparencia en el mercado ${ }^{55}$.

51 Sobre las técnicas de intervención ambiental en el sector del turismo, vid. M ${ }^{a}$.T. CARBALLEIRA RIVERA, "Por un turismo medioambientalmente correcto. Propuestas para el próximo milenio", en Estudios en homenaje al prof. Martín Mateo, Tirant lo blanch, Valencia, 2000, pp. 3112 y ss.

52 En este sentido, el Plan Senda propuso la redacción consensuada de una Carta del Paisaje Rural, en la que se contengan los principales compromisos de integración de los equipamientos turísticos en el medio y que debería acompañar a todo documento de ordenación turística en el espacio rural.

${ }^{53}$ Lo cierto es que ya la propia Ley 12/1999 -art. 32.3- establece que las instalaciones de los establecimientos turísticos se deberán conservar en adecuado estado, manteniendo los requisitos mínimos exigidos para su apertura y funcionamiento. Por lo demás, el Decreto 20/2002 -art. 8.2añade el mobiliario, equipamiento, personal, enseres y menaje serán, en su calidad, acordes con las características del servicio o establecimiento, encontrándose en buen estado de uso y conservación, debiendo adecuarse a los elementos decorativos y al mobiliario tradicionales de la comarca.

${ }^{54}$ Así, D. BLANQUER, "Régimen jurídico del turismo rural”, op. cit., p. 466.

${ }^{55}$ Vid., en general, D. BLANQUER, "La ordenación jurídica de la calidad del turismo”, en Estudios en homenaje al prof. Martín Mateo, Tirant lo blanch, Valencia, 2000, pp. 3121 y ss.; J. TUDELA ARANDA, "La problemática jurídica de la calidad turística", RArAP, núm. 23, 2003, pp. 131 y ss. 
De otro lado, como certeramente ha señalado TUDELA ARANDA, es evidente que la calidad del turismo rural no se reduce a la calidad del producto estrictamente turístico, sino que se extiende a la calidad del entorno mismo, lo que remite al alejamiento en relación con los establecimientos de turismo rural y posibles instalaciones contaminantes o molestas, cuestión tratada más arriba $^{56}$. Por ello, además del factor de calidad medioambiental en sentido estricto antes referido, se echa en falta una disposición en virtud de la cual se habilite a la Administración a denegar la solicitud de apertura de un establecimiento de turismo rural que se ubique en la proximidad de estructuras urbanas degradadas o que no dispongan de vías de acceso adecuadas, tal como la contenida en alguna Comunidad Autónoma ${ }^{57}$.

\section{EL ALOJAMIENTO TURÍSTICO EN EL MEDIO RURAL}

\subsection{Los alojamientos específicos del turismo rural}

\subsubsection{Caracteres generales.}

Como es sabido, el alojamiento constituye la oferta turística básica sobre la que en buena medida se asienta y hace posible todo el resto de actividades. Y, a este respecto, el turismo rural se caracteriza por la existencia de modalidades alojativas específicas, diversas de los tradicionales establecimientos hoteleros. De acuerdo con el Plan Senda elaborado por la entonces Consejería de Turismo y Deporte de la JA, los rasgos caracterizadores del concepto de "alojamiento específico del espacio rural" serían los siguientes: la integración en el entorno natural y humano del área; una relación con el cliente más personalizada que en otras tipologías turísticas; el respeto a las formas arquitectónicas tradicionales y la conservación del patrimonio artesanal y gastronómico preexistente. Y, en este sentido, el Decreto 20/2002 -art. 9.1- establece que los "alojamientos turísticos en el medio rural" (esto es, tanto los establecimientos de alojamiento turístico como las viviendas turísticas de alojamiento rural) deben poseer las condiciones siguientes:

\footnotetext{
${ }^{56}$ Como señala J. TUDELA ARANDA, "Hacia el desarrollo de un concepto integral de turismo rural", op. cit., pp. 73 y 84, la calidad está en la raíz misma de la oferta de turismo rural, de tal modo que a la calidad del producto estrictamente turístico debe añadirse la calidad del entorno.

${ }^{57}$ Decreto de Galicia 191/2004, de 29 de julio, de establecimientos de turismo rural -art. 54.3-.
} 
a) Reunir las características propias de la tipología arquitectónica de la comarca en la que estén situados. Se trata de un requisito característico de las casas rurales -como se tratará más adelante- y que el Decreto 20/2002 extiende a todos los alojamientos turísticos en el medio rural ${ }^{58}$. Y, a este respecto, parece lógico entender que corresponde a los instrumentos urbanísticos definir tipologías y características edificatorias, fundamentalmente en lo que se refiere al concepto de arquitectura tradicional según las peculiaridades de cada zona.

b) Estar integrados adecuadamente en el entorno natural y cultural. En este sentido, es un lugar común en los instrumentos de ordenación de los espacios naturales protegidos señalar que las edificaciones vinculadas a actividades de turismo deberán tener características constructivas que las integren el entorno paisajístico de la zona ${ }^{59}$. Más aún, debe recordarse que la LOUA -art. 57.1- establece, en una norma de aplicación directa, que las edificaciones en suelo no urbanizable deben presentar características tipológicas y estéticas adecuadas a su ubicación y a su integración en el entorno.

\subsubsection{Tipología de los diferentes alojamientos.}

Aun cuando la Casa Rural es -como se verá- la modalidad típica y característica de alojamiento en el medio rural, se considera conveniente articular una oferta más variada de modalidades de alojamiento en el espacio rural, con objeto de cubrir todas los posibles márgenes de actuación respecto a la creación de la oferta ${ }^{60}$. Así, junto a las casas rurales (completas y por habitaciones), es cada vez más frecuente introducir otras modalidades como campamentos de turismo rural, hoteles rurales, Villas Turísticas..., introduciendo cada Comunidad Autónoma las particularidades diferenciadoras de su propio ámbito rural frente a otros destinos competidores -denominaciones de los tipos de alojamiento, requisitos exigidos, tipologías edificatorias.... ${ }^{61}$.

\footnotetext{
${ }^{58}$ Criterio confirmado por el Decreto 47/2004, de 10 de febrero, de establecimientos hoteleros -art. 37.1-.

${ }^{59}$ Véase, p. j., los Decretos ya citados de los Parques Naturales Sierra Mágina, Bahía de Cádiz y Los Alcornocales.

${ }^{60}$ Así, el Plan Senda propugnó que se regulase un completo "Sistema de Alojamientos Específicos del Espacio Rural Andaluz".

${ }^{61}$ Así, p. j., el Decreto de Cantabria 31/1997 tipifica los Palacios y Casonas cántabras, las Posadas de Cantabria y Casas de Labranza; la Ley de Cataluña 13/2002 -art. 50- se refiere a las Casas de payés, o la Ley de Galicia 9/1997 -art. 47- se refiere a los pazos, casas de aldea y casas de labranza.
} 
En este sentido, mientras el anterior Decreto 94/1995 se ocupaba exclusivamente del alojamiento en casas rurales, la Ley 12/1999 introdujo la categoría de las viviendas turísticas de alojamiento rural y el actual Decreto 20/2002 contempla un conjunto de "alojamientos turísticos en el medio rural", que abarca tanto a los "establecimientos de alojamiento turístico" en sentido estricto, en sus distintas modalidades -casas rurales, establecimientos hoteleros, apartamentos turísticos rurales y complejos turísticos rurales-, como las viviendas turísticas de alojamiento rural. Asimismo, el Decreto 20/2002 -art. 10-admite una amplia gama de especialidades de los establecimientos en el medio rural, atendiendo, entre otros aspectos, a las características arquitectónicas, a los servicios prestados, a la motivación de la demanda o a su especial ubicación, especialmente cuando se trate de espacios naturales protegidos ${ }^{62}$.

\subsubsection{Clasificación de los alojamientos en categorías.}

El Plan Senda señaló que una de las principales carencias de turismo rural andaluz es la escasez de una oferta alojativa de calidad, entendiendo la calidad como referida tanto a la dotación y servicios prestados como en lo que atañe a la adecuación a las soluciones arquitectónicas autóctonas y la integración en el entorno físico y social del área. Por esta razón, además de la anterior diversificación en tipologías, se plantea la necesidad de establecer en lo posible una clasificación según niveles de calidad dentro de cada tipología, como fórmula de identificación comprensible ante los diferentes segmentos de demanda del grado de calidad alcanzado por cada establecimiento ${ }^{63}$. Y, en este sentido, a diferencia del Decreto 94/1995, el vigente Decreto 20/2002 distingue dos niveles de calidad para las casas rurales: de categoría básica y superior (Anexo III).

\subsection{La noción de Casa Rural}

Del conjunto de la legislación autonómica se desprende que las Casas Rurales -con esta u otra denominación ${ }^{64}$ - constituyen una modalidad de aloja-

${ }^{62}$ Así, el Anexo I tipifica las categorías siguientes: agroturismo, albergue, aulas de la naturaleza, casa forestal, casa molino, casas-cueva, chozas y casas de huerta, cortijo, granja-escuela, hacienda, refugio y otros alojamientos especiales, sujetos a autorización especial.

${ }^{63}$ Así, el Decreto del Gobierno de Aragón 69/1997 -art. 7- hace depender la diferencia entre categorías básicas y superior de las viviendas de turismo rural, fundamentalmente, en las características arquitectónicas del edificio y en la calidad del patrimonio cultural y natural del entorno en el que se ubica. Más aún, el Decreto del Gobierno de Extremadura 120/1998 -art. 8.2- diferencia tres tipos de categorías de casas rurales: básica, media y superior.

${ }^{64}$ La Ley de Asturias 7/2001 -art. 39- las denomina "casas de aldea". 
miento turístico extrahotelero que, además del emplazamiento en el medio rural $^{65}$-en el sentido tratado más arriba- se caracteriza por determinados requisitos materiales, sin perjuicio de que la concurrencia de tales requisitos materiales no sea suficiente para que un establecimiento adquiera la condición legal de casa rural, sino que la edificación debe ser formalmente declarada como tal por la Administración turística mediante un título administrativo habilitante $^{66}$.

\subsubsection{Vivienda independiente.}

Como precisan algunas normas, la Casa Rural debe constituir una vivienda independiente y autónoma ${ }^{67}$. Con esta afirmación se pretende diferenciar la casa rural de un mero alojamiento en pisos de propiedad horizontal. En este sentido, algunas normas explicitan que no tendrán la consideración de alojamientos rurales, cualquiera que sea su situación, los ubicados en pisos, entendiéndose por tales las viviendas independientes integradas en un edificio de varias plantas, sujeto a la Ley de Propiedad Horizontal, que no respondan a la arquitectura tradicional o propia del medio rural ${ }^{68}$. Asimismo, algunas normas imponen, además, un límite a las alturas de los edificios ${ }^{69}$.

En Andalucía, el antiguo Decreto 94/1995 -art. 2.3- excluyó a los pisos, entendiendo por tales "las viviendas independientes en un edificio de varias plantas, que no estén ubicadas en una casa tradicional”, sin fijar un límite de plantas. Por su parte, el Decreto 20/2002 -art. 15.1- establece que las casas rurales deben constituir viviendas de carácter independiente y no deben existir,

65 Ley de Extremadura 2/1997 -art. 32-; Ley de Galicia 9/1997 -art. 46.1-; Ley de Castilla y León 10/1997 -art. 26-; Ley de la Comunidad de Madrid 1/1999 -art. 29-.

66 Decreto Comunidad Valenciana 253/1994 -art. 12.1-; Ley de Extremadura 2/1997 -art. 32-; Decreto de Extremadura 120/1998 -art. 6-; Ley de Andalucía 12/1999 -art. 41-.

67 Ley de Extremadura 2/1997 -art. 32-; Decreto del Gobierno de Extremadura 120/1998 -art. 6-.

68 En términos muy similares: Decreto del País Vasco 128/1996 -art. 3-; Decreto del Gobierno de Aragón 69/1997 -art. 2.3-; Ley de Murcia 11/1997 -art. 22-; Decreto del Gobierno de Extremadura 120/1998 -art. 7.2-; Ley de Cataluña 13/2002 -art. 50.4-.

69 Así, el Decreto del Gobierno de la Comunidad Valenciana 253/1994 -art. 7.2- dispone que los edificios en los que se ubiquen las casas rurales no tendrán más de tres alturas, incluida la planta baja, si bien la reforma operada por el Decreto 207/1999 flexibilizó dicho límite, al admitir los casos de un único alojamiento que "por las características propias de su ubicación disponga de una o dos plantas más". 
en ningún caso, más de tres viviendas en el mismo edificio ${ }^{70}$. De este modo, el Decreto 20/2002 establece un límite máximo a la posibilidad de compartir un edificio y que no existía en el Decreto 94/1995. Asimismo, aun cuando el Decreto 20/2002 omite fijar una límite de alturas, dado que tal límite sí se establece -art. 17.1- en relación con los establecimientos hoteleros -tres plantas-, no debería existir dificultad para entender que tal límite, con mayor razón, es aplicable a las casas rurales (y viviendas turísticas de alojamiento rural). Asimismo, debe recordarse que la LOUA -art. 57.1- establece, en una norma de aplicación directa, que las edificaciones en suelo no urbanizable no deben tener más de dos plantas, salvo prescripción imperativa distinta del PGOU o Plan Especial.

\subsubsection{Características arquitectónicas.}

Es también lugar común el requisito según el cual el edificio debe reunir determinadas características especiales de construcción y tipicidad, no tanto en el sentido que la edificación tenga una cierta antigüedad -si bien en algunas Comunidades sí se exige, lo cual supone un importante elemento diferenciador ${ }^{71}$ - como en el sentido que responda a los modelos de arquitectura tradicional de la zona en la que esté emplazada, ya sea un edificio preexistente, producto de rehabilitación o de nueva construcción ${ }^{72}$. Como ya se avanzó antes, el Decreto 20/2002 optó por extender esta exigencia a todos los "alojamientos turísticos en el medio rural".

\subsubsection{Instalaciones y equipamientos.}

Las casas rurales deben estar dotadas de las instalaciones, mobiliario y servicios mínimos, y reunir las debidas condiciones de habitabilidad que reglamentariamente se determine ${ }^{73}$. Con todo, el único elemento conceptual con-

\footnotetext{
${ }^{70}$ De modo similar, el Decreto de Canarias 18/1998 -art. 3- establece que los inmuebles de casas rurales destinados a alojamiento de uso compartido podrán ser subdividios en tres unidades alojativas como máximo.

${ }^{71}$ Decreto de las Islas Baleares 62/1995 -art. 2-; Decreto de Cataluña 214/1995 -art. 3-; ; Decreto de Canarias 18/1998 -art. 5-.

${ }^{72}$ Ley de Extremadura 2/1997 -art. 32-; Decreto de Extremadura 120/1998 -art. 7.1-; Ley de Galicia 9/1997 -art. 46.1-; Ley de Castilla y León 10/1997 -art. 26-; Decreto de Asturias 26/1991 -art. 2.a)-; Decreto de Navarra 105/1993 -art. 3-; Decreto de Castilla y León 84/1995 -art. 5.2-; Decreto de Cataluña 214/1995 -art. 3.2-; Decreto de Aragón 69/1997 -art. 2-.

${ }^{73}$ Ley del País Vasco 6/1994 -art. 26-; Ley de Murcia 11/1997 -art. 13-; Decreto de Extremadura 120/1998 -art. 7.1-.
} 
siste en la sujeción a unas exigencias mínimas de infraestructuras, pero cuáles deban ser estas es, evidentemente, una cuestión de régimen jurídico, razón por la que se examina más adelante. Ahora bien, un innegable factor de calidad viene constituido por la imposición de una extensión mínima en el entorno inmediato del establecimiento de alojamiento rural, requisito ausente para las Casas Rurales en el Decreto 20/2002, ni siquiera para las de categoría superior $^{74}$.

\subsubsection{Capacidad máxima.}

La cuestión de fijar un límite a la capacidad alojativa de los establecimientos obedece a la necesidad de armonizar la viabilidad económica de la empresa con la necesidad de diferenciar este alojamiento turístico del hotelero. En este punto los criterios son notablemente diversos: desde 6 a 16 plazas $^{75}$. En Andalucía, el Decreto 94/1995 -art. 2- fijó un máximo de 15 plazas, que era ya una capacidad elevada en relación con la media autonómica. Por su parte, el Decreto 20/2002 -art. 15.1- ha incrementado aún más dicha capacidad, al establecer un máximo de 20 plazas $^{76}$.

\subsection{5. ¿Servicios complementarios?}

En general, las normas autonómicas únicamente exigen que en las Casas Rurales se faciliten la prestación de alojamiento, con o sin manutención u otros servicios complementarios, que tienen, por tanto, un carácter even-

\footnotetext{
${ }^{74}$ Así el Decreto de Galicia 191/2004 exige que las casas de labranza cuenten con una extensión mínima de $5.000 \mathrm{~m} 2$, de los cuales al menos el $40 \%$ debe estar situado en el entorno inmediato de la vivienda.

756 plazas: (Cantabria), 10 plazas (Decreto de Asturias 26/1991; Decreto de la Comunidad Valenciana 253/1994 -art. 8.3-, si bien la reforma del Decreto 207/1999 amplió la capacidad máxima a 12 plazas, incluidas camas supletorias), 12 plazas (Decreto de la Región de Murcia 79/1992 -art. 6-; Decreto del País Vasco 128/1996 -art. 3-). Tanto el Decreto de Castilla-La Mancha 43/1994 -art. 3-, como el Decreto de Aragón 69/1997 -art. 2- y el Decreto de Extremadura 120/1998 -art. 7.1- exigen para las Casas Rurales un mínimo de dos habitaciones y un máximo de seis), 15 plazas (Decreto de Canarias 18/1998 -art. 3-) o 16 plazas (Decreto Foral 243/1999 -art. 3- y Decreto de La Rioja 26/2000 -art. 5-, que elevó el límite de 12 plazas del Decreto 8/1995).

${ }^{76}$ Curiosamente el Borrador de Decreto contemplaba reducir de 15 a 12 plazas la capacidad de las casas rurales.
} 
tual $^{77}$. Como mucho, en algunas Comunidades Autónomas se establecen servicios mínimos para determinadas modalidades de alojamiento compartido ${ }^{78}$. En cambio, en Andalucía se ha seguido un criterio diverso, tal como se verá inmediatamente.

\subsection{La distinción entre casas rurales y viviendas turísticas de alojamiento ru- ral en el ordenamiento andaluz}

\subsubsection{Las casas rurales en la Ley 12/1999}

De la sistemática empleada por la Ley $12 / 1999^{79}$ se infiere que las casas rurales son "establecimientos de alojamiento turístico", lo que supone su sujeción a las reglas comunes a todos los establecimientos turísticos -arts. 31 a 33 Ley $12 / 1999^{80}$. Asimismo, la Ley -art. 41.1- define a las casas rurales como

${ }^{77}$ Ley del País Vasco 6/1994 -art. 25-; Orden de Castilla y León de 27-10-1995 -art. 21-; Ley de Extremadura 2/1997 -art. 32-; Ley de Murcia 11/1997 -art. 13-; Decreto de Aragón 69/1997 -art. 1-; Decreto de Canarias 18/1998 -art. 7-; Decreto Foral 243/1999 -art. 17-; Ley de la Comunidad de Madrid 1/1999 -art. 25-; Ley de Baleares 2/1999 -art. 14-; Ley de La Rioja 2/2001 -art. 16.1-; Ley de Asturias 7/2001 -art. 39.1-, en relación con las casas de aldea; Ley de Aragón 6/2003 -art. 43-.

${ }^{78}$ Los Decretos de Castilla-La Mancha 43/1994 -art. 6-, de Aragón 69/1997 -art. 9- ,de Extremadura 120/1998 -art. 12.e) - y de La Rioja 26/2000 -art. 9- obligan, en caso de alojamiento compartido o por habitaciones, a ofrecer servicio de desayuno exclusivamente a los clientes, para los cuales tiene un carácter opcional. Por su parte, el Decreto de Extremadura 120/1998 -art. 9ordena que, en caso de casas rurales de alojamiento compartido o bien no compartido en régimen de contratación individualizada por habitaciones, los servicios mínimos incluidos en el precio serán los de alojamiento y desayuno. Criterio seguido por el Decreto de Galicia 191/2004, de 29 de julio, de establecimientos de turismo rural -art. 9-.

${ }^{79}$ La Ley regula las Casas Rurales en el Título V relativo a la "Ordenación de la Oferta Turística", y dentro del Capítulo III referente a "Los establecimientos y servicios turísticos en particular", y, a su vez, dentro de la Sección 1르 dedicada a los "Establecimientos de alojamiento turístico". En este sentido, el art. 36.1.e) de la Ley incluye expresamente a las casas rurales entre los tipos de "establecimientos de alojamiento turístico".

${ }^{80}$ Las casas rurales están sujetas obligatoriamente a la inscripción en el Registro de Turismo de Andalucía -art. 35.1 en relación con el art. 34.1.a)-, y ello aunque no concurra en el titular la condición de empresario -art. 35.1-. Asimismo, las casas rurales deben cumplir los requisitos de instalaciones, mobiliario y servicios que reglamentariamente se determine -art. 36.3-. Habilitación legal que no es sino una concreción de la habilitación contenida en el art. 32 en relación con los requisitos de infraestructura, seguridad y medio ambiente de los establecimientos turísticos en general. 
"aquellas edificaciones situadas en el medio rural que, por sus especiales características de construcción, ubicación y tipicidad, prestan servicios de alojamiento, con otros servicios complementarios, y que hayan sido declaradas como tales por la Administración turística" ${ }^{81}$.

El aspecto más destacable de la Ley andaluza es que el establecimiento debe prestar, además de servicios de alojamiento, otros servicios complementarios. Se trata de una exigencia no contenida en el Decreto de Casas Rurales 94/1995, en el cual la prestación de servicios complementarios - como servicios de cocina o derecho a utilizar la cocina de la casa- tenía un carácter potestativo. Debe, asimismo, observarse que esta exigencia de oferta de servicios complementarios no es una condición exigida, con carácter general, a los establecimientos de alojamiento -art. 27.1.a)-, ni de hecho se encuentra ordenada en el resto de los establecimientos de alojamiento turístico, ni siquiera en los establecimientos hoteleros -art. 37.1-. Este requisito adicional sirve para diferenciar, en la sistemática de la Ley andaluza, a las casas rurales de las viviendas turísticas de alojamiento rural -art. $44{ }^{82}$.

\subsubsection{Las Viviendas turísticas de alojamiento rural en la Ley 12/1999.}

Como se ha señalado más arriba, la Ley 12/1999 contempla, además de las casas rurales, las llamadas viviendas turísticas de alojamiento rural. La Ley regula esta figura en el Capítulo III referente a "Los establecimientos y servicios turísticos en particular", pero no en la Sección 1" dedicada a los "Establecimientos de alojamiento turístico" -como sucedía con las casas rurales-, sino

\footnotetext{
${ }^{81}$ Puede observase una cierta incorrección de sintaxis. De tenor literal del precepto parecería que las casas rurales prestan servicios de alojamiento y otros "por sus especiales características de construcción, ubicación y tipicidad", lo cual es evidentemente absurdo. La redacción correcta debería haber sido: "Son casas rurales aquellas edificaciones situadas en el medio rural que, por sus especiales características de construcción, ubicación y tipicidad, y por prestar servicios de alojamiento junto con otros servicios complementarios, hayan sido declaradas como tales por la Administración turística".

${ }^{82}$ La razón de la introducción de este requisito parece obedecer a motivos fiscales. En efecto, de acuerdo con la respuesta a una consulta de la D.G. de Tributos de 29.01.1998, para que la utilización de una vivienda rural esté exenta del IVA, ha de tratarse "exclusivamente" de un arrendamiento, de modo que el arrendador no se obliga a prestar servicio complementario adicional alguno propio de la industria hotelera. Vid. F.J. MELGOSA ARCOS, "La ordenación del turismo rural: aspectos administrativos, fiscales y laborales", en I y II Jornadas de Turismo y Derecho, Junta de Andalucía, Málaga, 1999, pp. 142-143.
} 
en la Sección 2a "De las viviendas turísticas", junto con las viviendas turísticas vacacionales ${ }^{83}$.

De este modo, las viviendas turísticas -y entre ellas las de alojamiento rural- no son, formalmente, "establecimientos de alojamiento turístico", pues no están contempladas en el art. 36.1 de la Ley 12/1999 ni, en consecuencia, reguladas en la Sección 1 a , relativa a los "Establecimientos de alojamiento turístico". Asimismo, la Ley 12/1999 -art. 36.4- admite expresamente la existencia de otros establecimientos distintos de los catalogados por la Ley como "establecimientos de alojamiento turístico" que, no obstante, pueden prestar el servicio de alojamiento turístico. A nuestro modo de ver, no deja de ser arbitrario considerar que un establecimiento, que se reconoce legalmente que presta un servicio de alojamiento turístico, no es legalmente un "establecimiento de alojamiento turístico". En todo caso, aun cuando el modo de proceder de la Ley es discutible, es clara la finalidad, que no es otra que eludir la aplicación a estos establecimientos del régimen jurídico propio de los "establecimientos de alojamiento turístico", con las consecuencias legales que ello comporta ${ }^{84}$.

En todo caso, la Ley 12/1999 -art. 44- declara que "Son viviendas turísticas de alojamiento rural aquéllas que cumplan con las especiales características definidas para las casas rurales, siempre que en ellas no se preste ningún servicio distinto del alojamiento". De este modo, las viviendas turísticas presentan las mismas características de emplazamiento -en el medio rural- y estructurales -características especiales de construcción, ubicación y tipicidad- que las casas rurales, y la diferencia estriba exclusivamente en la circunstancia de que deben

\footnotetext{
${ }^{83}$ La noción de "viviendas turísticas" procede del Real Decreto de 15 de octubre 1982, el cual no consideró como apartamentos turísticos, sino viviendas turísticas vacacionales a las unidades aisladas de apartamentos, bungalow, villas y chalés y similares y, en general, cualquier vivienda que con independencia de sus condiciones de mobiliario, equipo, instalaciones y servicios, se ofrezcan $\mathrm{n}$ régimen de alquiler por motivos vacacionales o turísticos -art. 17-.

${ }^{84}$ Básicamente, mientras la Ley -art. 35.1-impone el carácter preceptivo de la inscripción en el Registro de Turismo para los "establecimientos de alojamiento turístico", tal exigencia no sería aplicable a las viviendas turísticas. Por el contrario, aun cuando las viviendas turísticas carecen de la condición formal de "establecimientos de alojamiento turístico", de la ubicación y regulación de las mismas contenida en la Ley -dentro del Título V relativo a la "Ordenación de la Oferta Turística", y, a su vez, dentro del Capítulo III referente a "Los establecimientos y servicios turísticos en particular", parece incuestionable que tales "establecimientos" prestan "servicios turísticos" -art. 2.c) y f)-, de modo que les son aplicables las reglas generales contenidas en el Capítulo I referentes a los servicios y establecimientos turísticos en general -libertad de prestación de servicios turísticos, precios, requisitos de infraestructura...-.
} 
prestar, únicamente, servicios de alojamiento, al igual que las viviendas turísticas vacacionales -art. 43.1-, pues en caso contrario, es decir, de prestar servicios complementarios, tendrían la condición de casa rural ${ }^{85}$.

3.3.3. Las Casas Rurales y las viviendas turísticas de alojamiento rural en el Decreto $20 / 2002$

A pesar de todo lo anterior, el Decreto 20/2002 optó por relativizar la diferencia antes clara en la Ley entre casas rurales y viviendas turísticas de alojamiento rural. De entrada, agrupa a ambas nociones en una categoría de "alojamientos turísticos en el medio rural”, que somete a una régimen común, de condiciones generales -art. 9.1-, de requisitos mínimos de infraestructura -art. 11 y Anexo II-, servicios mínimos -art. 12.1-, régimen de dispensas -art. 14-, distintivos y publicidad -art. 35-1-, obligaciones de titulares -art. 36-, y facturación y pago de los servicios -art. 37-. Seguidamente, establece idénticos requisitos materiales para las casas rurales y las viviendas turísticas de alojamiento rural: ha de tratarse de viviendas de carácter independiente y no existir, en ningún caso, más de tres viviendas en el mismo edificio; la capacidad máxima es idéntica de 20 plazas -arts. 15.1 y 19.1-; el alojamiento ha de disponer de los elementos necesarios para su inmediata utilización, y se extienden a las viviendas turísticas de alojamiento rural las prescripciones específicas de las casas rurales de categoría básica -art. 19.2 y Anexo III-. Ahora bien, aun cuando la exposición de motivos del Decreto 20/2002 sigue refiriéndose a la exigencia de que las casas rurales ofrezcan otros servicios complementarios, lo cierto es que el articulado de la disposición no plasma tal exigencia, en abierta contradicción con lo establecido en la Ley 12/1999.

De este modo, la única distinción sustancial entre casas rurales y viviendas turísticas de alojamiento rural en el Decreto 20/2002 consiste en que las primeras "pueden" -no ya deben- prestar servicios complementarios al alojamiento -art. 13-, mientras que las viviendas turísticas de alojamiento rural deben prestar exclusivamente el servicio de alojamiento -art. 19.1-, sin que puedan ofrecer dichos servicios complementarios -art. 13 a sensu contrario-. Lo cierto es que, una vez rectificado el criterio de la Ley 12/1999, la diferencia entre casa rural y vivienda turística de alojamiento rural aparece ya como un

${ }^{85}$ Finalmente, la Ley -art. 45- establece que las viviendas turísticas, incluidas por tanto las de alojamiento rural, deben estas amuebladas y disponer de los enseres necesarios para su inmediata utilización. 
artificio, de tal modo que es comprensible que en otras Leyes autonómicas haya desaparecido ${ }^{86}$.

\subsection{Modalidades de prestación del servicio de alojamiento}

Aun cuando no siempre la legislación autonómica contemple todas las modalidades posibles, en función de su régimen de explotación o alojamiento, las casas rurales pueden clasificarse en dos tipos, según se ceda el uso de una o varias habitaciones de una misma vivienda o, por el contrario, se ceda el uso de todo el establecimiento o de una o varias viviendas autónomas integradas en el mismo.

\subsubsection{Régimen de uso por viviendas.}

En este tipo de alojamiento no compartido, en el cual el establecimiento se dedica exclusivamente a hospedaje, cada una de las viviendas que constituyan una unidad de alojamiento -y de contratación- han de disponer de las condiciones de equipo, instalaciones y servicios -cocina, comedor, baño...que permitan su inmediata utilización ${ }^{87}$. A su vez, se diferencian dos modalidades:

a) Cesión del establecimiento en su totalidad.

En esta modalidad el titular del establecimiento ofrece el uso y disfrute del mismo en su integridad, como unidad de alojamiento y contratación ${ }^{88}$. En esta modalidad de explotación la principal cuestión que se plantea consiste en delimitar esta actividad turística de la mera actividad de alquiler sujeta a la legislación de arrendamientos. Así, en algunas Comunidades Autónomas se define esta modalidad como "cara rural en régimen de alquiler" 89 , mientras que en otras, por el contrario, se denomina a esta modalidad "Casa de Turismo Ru-

\footnotetext{
${ }^{86}$ Así, la Ley de Aragón 6/2003 -art. 43- únicamente ordena las "viviendas de turismo rural", en sus modalidades de prestación del servicio de alojamiento.

${ }^{87}$ Decreto de Aragón 69/1997 -art. 4.1-; Decreto de Extremadura 120/1998 -art. 8.1-.

${ }^{88}$ Decreto de Aragón 69/1997 -art. 4.1-; Decreto de Extremadura 120/1998 -art. 8.1-; Ley de Asturias 7/2001 -art. 39.2-.

${ }^{89}$ Ley de Murcia 11/1997 -art. 22-.
} 
ral propiamente dicha" ${ }^{90}$. La diferencia únicamente puede estribar en que la casa se destine o no a alojamiento turístico de forma habitual y profesional, mediante precio, con o sin servicios complementarios ${ }^{91}$, criterio complementado por otros elementos normativos -como sujeción a períodos de apertura y plazos máximos de alojamiento... -. En este sentido, algunas normas precisan que en los casos en que el titular no gestione directamente el alojamiento, deberá designar un encargado que habrá de facilitar el alojamiento y resolver cuantas incidencias surjan de los usuarios ${ }^{92}$.

b) Cesión del establecimiento por viviendas autónomas.

En esta modalidad el establecimiento se estructura en dos o más unidades de vivienda autónomas, esto es como conjuntos independientes de habitaciones que dispongan como mínimo de cocina, salón, dormitorios y baño, y que puedan ser objeto de inmediata utilización. En este caso, a los problemas anteriores, se suma el riesgo de desvirtuar el sentido originario de este producto turístico, mediante un mero alojamiento en pisos o apartamentos. Con objeto de evitar este riesgo, las normas establecen límites a esta modalidad. Así, como se ha señalado antes, el Decreto 20/2002 -art. 15.1- establece que no deben existir, en ningún caso, más de tres viviendas en el mismo edificio ${ }^{93}$.

\subsubsection{Régimen de alojamiento por habitaciones.}

En estos casos el alojamiento en la vivienda puede ser compartido con otros usuarios o con el propio titular del establecimiento ${ }^{94}$. De este modo, caben dos modalidades.

${ }^{90}$ Decreto de Aragón 69/1997 -art. 4.1-.

91 Ley de Baleares 2/1999 -art. 14-; Ley de La Rioja 2/2001 -art. 16.1-; Ley de Cataluña 13/2002 -art. 49.1-; Decreto de la Comunidad Valenciana 253/1994 -arts. 2.1 y 5-.

92 Decreto Foral 243/1999 -art. 18-, quien precisa que el encargado del establecimiento debe encontrarse a disposición de los clientes dentro del núcleo de población donde se ubique el establecimiento; Ley de Asturias 7/2001 -art. 39.2-; Decreto de Andalucía 20/2002 (Anexo III).

${ }^{93}$ En sentido similar, Decreto de Canarias 18/1998 -art. 3-.

${ }^{94}$ Decreto de la Comunidad Valenciana 253/1994 -art. 3.a)-. 


\section{a) Hospedaje por habitaciones.}

En estos casos se posibilita el hospedaje de la misma casa rural al mismo tiempo a diversos usuarios ${ }^{95}$. En última instancia, en esta modalidad la casa rural no se diferenciaría de un establecimiento hotelero o similar. De aquí que las normas autonómicas, para marcar las diferencias, establezcan unos límites más o menos rigurosos a la capacidad de hospedaje del establecimiento, con objeto de no desnaturalizar el servicio o producto turístico. Así, como se indicó más arriba, el Decreto 20/2002 -art. 15.1- fijó una capacidad comparativamente muy alta, al establecer un máximo de 20 plazas.

b) Casas rurales en régimen de alojamiento compartido: el agroturismo.

En ellas el titular del establecimiento comparte el uso de su propia vivienda con una zona o anexo dedicada al hospedaje ${ }^{96}$, la cual se podrá contratar en su totalidad o por habitación ${ }^{97}$. Configurada en ocasiones como una categoría autónoma a la de la casa rural ${ }^{98}$, y otras como una modalidad específica de la Casa Rural (de hecho, su modalidad primigenia ${ }^{99}$ ), el agroturismo se caracteriza porque la casa no sólo se encuentra ubicada en el medio rural, sino específicamente dentro de una explotación agraria (agrícola, ganadera o forestal) en activo ${ }^{100}$. En principio la actividad de agroturismo se concibe com-

${ }^{95}$ Así, la Ley de Murcia 11/1997 -art. 22- define la Hospedería rural como "establecimientos ubicados en edificaciones con valor arquitectónico, histórico o cultural, cedidos a los usuarios en régimen de alquiler por habitaciones". O La Ley de Asturias 7/2001 -art. 39.3- define como una de las modalidades de prestación del alojamiento turístico en casas de aldea, la contratación individualizada de habitaciones dentro de la propia vivienda familiar, incluyendo el desayuno. Igualmente, el Decreto de Extremadura 120/1998 -art. 8.1- prevé una modalidad de alojamiento no compartido en régimen de contratación por habitaciones individualizadas.

${ }^{96}$ Ley de Murcia 11/1997 -art. 22-; Decreto de Aragón 69/1997 -art. 4.1-.

${ }^{97}$ Decreto de Extremadura 120/1998 -art. 8.1-.

${ }^{98}$ Es el caso de la Ley de Extremadura 2/1997 -art. 33-, si bien la propia Ley precisa que cuando en la actividad de agroturismo se preste alojamiento, con o sin manutención, éste se regirá por lo establecido ara las casas rurales. Por su parte, la Ley de Cataluña 13/2002 denomina a esta modalidad casas de payés, como grupo diferenciado del resto de alojamientos rurales.

99 Así, G.E. PALACIO Y DE MONTEMAYOR, "Régimen jurídico del turismo rural", RArAp, núm. 14, 1999, p. 633.

100 Debe recordarse que la Ley 19/1995, de 4 de julio, de Modernización de Explotaciones Agrarias, al definir éstas -art. 2.3- incluye como elemento de las mismas la vivienda con dependencias agrarias y considera que las actividades turísticas realizadas por el agricultor profesional en su explotación son complementarias de las propiamente agrarias -art. 2.5-. 
plementaria de la actividad agraria habitual y principal ${ }^{101}$. De aquí que algunas normas exijan que la vivienda debe estar habitada por agricultores ${ }^{102}$, o que los titulares de las casas deben obtener rentas de la actividad agraria, ganadera o forestal ${ }^{103}$, o bien que la extinción de la explotación agrícola, ganadera o forestal supone la automática revocación de la autorización turística ${ }^{104}$. En cuanto a los servicios, en la especialidad de agroturismo es común exigir que, junto al hospedaje, deben ofrecerse servicios complementarios de participación en las propias tareas agrarias ${ }^{105}$.

Por su parte, el Decreto 20/2002 (Anexo I) tipifica entre las especialidades de los establecimientos de alojamiento en el medio rural, el agroturismo, entendiendo por tal el alojamiento en una explotación agropecuaria en activo, en la que, como actividad complementaria, el turista pueda participar en tareas tradicionales propias de la explotación.

\subsection{Requisitos de los establecimientos de alojamiento de turismo rural}

\subsubsection{Requisitos relativos al titular del establecimiento}

Ha sido común que las normas autonómicas imponer requisitos específicos para adquirir la condición de titular de las Casas Rurales, y que suponen una fuerte limitación a la libertad de empresa, exigencias sustentadas, en última instancia, en la consideración del turismo rural como actividad complementaria de las explotaciones agrarias, en si bien debe señalarse que este tipo de exigencias se encuentran en retroceso, debido a la indicada evolución expansiva de la noción de turismo rural ${ }^{106}$.

${ }^{101}$ Ley de Extremadura 2/1997 -art. 33-.

${ }^{102}$ Ley del País Vasco 6/1994 -art. 25-.

${ }^{103}$ Ley de Cataluña 13/2002 -art. 50.2-.

${ }^{104}$ Ley de Baleares 2/1999 -art. 27-. La Ley de Baleares 2/1999 -art. 27- exige que la explotación ocupe una superficie mínima que, cuando comprenda varias fincas deberán ser colindantes, con un número de plazas limitado.

${ }^{105}$ Decreto de Extremadura 120/1998 -art. 39-; Ley de Asturias 7/2001 -art. 37.3-.

106 Sobre la evolución experimentada en la legislación valenciana, vid. R. TEROL GÓMEZ, "Régimen jurídico de los alojamientos turísticos rurales en la Comunidad Valenciana", RarAP núm. 17, 2000, pp. 401 y ss. Así, en la exposición de motivos del Decreto 207/1999, de 9 de no- 
-Persona física. En este punto se aprecia una diversidad de criterios, pues algunas normas, en particular las más antiguas, exigen que el titular del establecimiento sea una persona física ${ }^{107}$, mientras que otras disposiciones (Galicia y Castilla y León) admiten que los empresarios de turismo rural sean tanto personas físicas como jurídicas. Evidentemente, la exclusión de las personas jurídicas obedece a la finalidad de reservar los beneficios del ejercicio de esta actividad a los habitantes del medio rural, con objeto de que puedan mejorar sus rentas y evitar la despoblación del campo. Ahora bien, a nuestro modo de ver, restringir el acceso a esta actividad empresarial a las personas físicas es de dudosa constitucionalidad, pues sería contrario a la libertad de prestación de los servicios turísticos como manifestación de la libertad de empresa, y que se encuentra explicitada en algunas Leyes autonómicas (como es el caso de la Ley de Andalucía 12/1999 -art. 28.1-), máxime si se tiene presente que ordinariamente se trata de disposiciones reglamentarias ${ }^{108}$. Distinto es que la política de fomento se pueda circunscribir a las personas físicas, si bien en tal caso para que la discriminación no sea tachada de infundada es preciso añadir alguna circunstancia adicional, añadida a la condición de personas físicas ${ }^{109}$. Y esto nos lleva derechamente a otro de los requisitos que se manejan en esta materia. En cualquier caso, el ordenamiento andaluz no contiene tal exigencia, ni en el anterior Decreto 94/1995 ni en el actual Decreto 20/2002.

viembre, se señala que la creciente demanda por una sociedad urbana de turismo de rural y de interior, y la consiguiente perspectiva de explotación de dicho alojamiento como actividad empresarial, ha conducido a que la realidad supere las estrictas condiciones reglamentarias que imponía la norma anterior, "surgiendo iniciativas empresariales de explotación de alojamiento rural que unas veces se pretenden por personas jurídicas y otras superan la vecindad local o vinculación local del explotador". Asimismo, como señala C. FERNÁNDEZ RODRÍGUEZ, Derecho administrativo del turismo, Marcial Pons, Madrid, 2001, p. 190, desde la perspectiva de la iniciativa privada, la complejidad y multiplicidad de requisitos para la creación de estas empresas ha dificultado la actuación de los inversores.

${ }^{107}$ Decreto Comunidad Valenciana 253/1994 -art. 6.3-; Decreto de Aragón 69/1997 -art. 3-.

${ }^{108}$ En este sentido, C. SANZ DOMÍNGUEZ, op. cit., p. 77. Por su parte, D. BLANQUER, "Régimen jurídico del turismo rural", op. cit., p. 463, considera que este tipo de disposiciones invaden la competencia de regulación del estatuto del empresario reservada al Estado. A nuestro modo de ver, más que una cuestión competencial, se trata de un problema de insuficiente rango de las disposiciones reglamentarias en relación con la libertad de empresa.

${ }^{109}$ En este sentido, cabe reseñar que el Decreto Comunidad Valenciana 253/1994 fue reformado mediante Decreto 207/1999, por el cual se suprimieron todas las exigencias relativas a la condición de persona física y empadronamiento del titular del establecimiento. 
-Residencia en el medio rural. Con distintas variantes, en algunas Comunidades Autónomas se exige que el titular de la actividad resida, de hecho o de derecho, en el municipio o comarca donde ejerza la actividad turísti$\mathrm{ca}^{110}$, e incluso debiendo acreditar una antigüedad mínima en dicha residencia $^{111}$. Se trata, pues, del mencionado criterio de arraigo en el medio rural, que tiene la finalidad arriba indicada y al que son aplicables las consideraciones anteriores ${ }^{112}$.

-Profesión principal ligada al sector agropecuario. También aquí se observa cierta diversidad de criterios. Las Comunidades Autónomas de Andalucía, Cantabria, Castilla y León, Murcia, Navarra y La Rioja, no incluyen esta exigencia, mientras que las Comunidades Autónomas de Asturias, Cataluña, Castilla-La Mancha, País Vasco y Valencia exigen que la actividad de alojamiento turístico sea complementaria de la actividad profesional agraria habitual, o bien se exige que la actividad turística se realice en fincas que sean explotaciones agrarias, aun cuando no se exija que el titular del alojamiento turístico ejerza personalmente la actividad agropecuaria (Islas Baleares). A nuestro modo de ver, esta exigencia tiene sentido en una modalidad concreta de turismo rural, el agroturismo, pero supondría una restricción insalvable para el desarrollo del sector su generalización al conjunto del turismo rural.

-Aseguramiento de responsabilidad civil. Algunas Comunidades Autónomas imponen la suscripción de una póliza de responsabilidad civil que cubra los riesgos de los clientes dentro de la Casa Rural ${ }^{113}$. En el caso andaluz, el Decreto 20/2002 no impone tal exigencia, que parece impropia de un establecimiento de alojamiento. Cuestión distinta sería en caso de que el

${ }^{110}$ Decreto Comunidad Valenciana 253/1994 -art. 6.1-, el cual exigía el empadronamiento o le desarrollo de una actividad económica en el municipio, requisito éste derogado por el Decreto 207/1999; Decreto de Castilla y León 84/1995 -art. 7-; Decreto de Aragón 69/1997 -art. 3-; Decreto de Extremadura 120/1998 -arts. 7.1 y 33.5-; Decreto de La Rioja 26/2000 -art. 5-.

${ }^{111}$ Los Decretos de Castilla y León 84/1995 -art. 7-y de Aragón 69/1997 -art. 3- exigen una residencia mínima previa de seis meses, exigiendo la correspondiente certificación del Ayuntamiento que acredite esta circunstancia -art. 13.1-.

112 Ya el Manual del Planificador de Turismo Rural, publicado por la Secretaría General de Turismo en 1992 indicaba la exigencia de implicar la participación activa de la población local.

113 Decreto del País Vasco 191/1997 -art. 38-; Decreto de Extremadura 120/1998 -art. 33.6-; Decreto Foral 243/1999 -art. 7-; Decreto de Galicia 191/2004 de establecimientos de turismo rural -art. 54.3-. 
titular de la casa rural organice servicios de turismo activo, pues deberá naturalmente cumplir las prescripciones correspondientes -art. 23.1 Decreto 20/2002-114.

-Cualificación. Por el contrario, sí parece acertada la exigencia contenida en alguna norma autonómica (Decreto Foral 105/1993) en el sentido de requerir para ejercer esta actividad económica la previa obtención de un certificado de capacitación para la gestión de casas rurales expedido por la Administración autonómica.

\subsubsection{Requisitos relativos al establecimiento.}

Las normas autonómicas tratan de garantizar la calidad de la oferta mediante la regulación de los requisitos de instalaciones, equipamientos y servicios mínimos que deben reunir los establecimientos alojativos. Sin embargo, se trata de una cuestión delicada puesto que si los niveles son excesivamente altos se corre el riesgo cierto de que los establecimientos existentes no puedan cumplirlos, quedando en una situación de "paralegalidad". Por esta razón, parece conveniente diferenciar entre las distintas modalidades de establecimientos alojativos de turismo rural, pues no parece que deban ser idénticas las exigencias de instalaciones de una casa de agroturismo que de un hotel rural. E, incluso, en una misma modalidad de establecimiento, como es la casa rural, se observa una tendencia reciente orientada a diversificar la oferta de servicios turísticos en función de los niveles de prestaciones y servicios ofrecidos, con objeto adaptar la oferta a los distintos tipos de demanda de servicios turísticos. Y todo ello sin perjuicio de que desde las Administraciones competentes se apoye económicamente a las empresas del sector para que puedan adaptar sus establecimientos a las exigencias mínimas legales.

Así, el Decreto 20/2002 -art. 11- establece que los alojamientos turísticos en el medio rural, además de cumplir las normas en materia de construcción y edificación, instalación y funcionamiento de maquinaria, sanidad, contra-incendios, accesibilidad, medioambientales y demás que le resulten de aplicación, deberán disponer de la infraestructura mínima establecida en el mismo. Ahora bien, tal como se anticipó más arriba, a diferencia del 94/1995, el vigente Decreto 20/2002, junto con unos requisitos mínimos comunes a todas

\footnotetext{
${ }^{114}$ En este sentido, Decreto de Castilla y León 84/1995 -art. 9-.
} 
las casas rurales (Anexo II), establece unas prescripciones específicas según se trate de casas rurales de categoría básica o superior (Anexo III) ${ }^{115}$.

En general, la dotación de las casas rurales es muy variable por Comunidades Autónomas y, dentro de ellas, en función del régimen de explotación y de la categoría. No obstante, pueden identificarse algunos elementos comunes: agua corriente potable; agua caliente al menos en cuatros de baño; electricidad $^{116}$; calefacción al menos en algunos puntos que permitan un mínimo de confort ${ }^{117}$; un cuarto de baño por cada número determinado de plazas de alojamiento o fracción ${ }^{118}$; equipo sanitario de primeros auxilios ${ }^{119}$; disponibilidad de comunicación telefónica ${ }^{120}$; que todas las habitaciones tengan ventilación directa al exterior ${ }^{121}$; sistema de recogida de residuos sólidos y de evacuación de aguas residuales ${ }^{122}$; medidas de prevención de y extinción de in-

${ }^{115}$ Ya el Decreto de Aragón 69/1997 -art. 7- diferenció en las viviendas de turismo rural entre una categoría básica y una categoría superior.

${ }^{116}$ Decreto de Aragón 69/1997 -art. 7.1.1-. El Decreto 253/1994 Comunidad Valenciana -art. 8.1- y el Decreto de Extremadura 120/1998 -art. 11.A)- exigen puntos y tomas de luz en todas las habitaciones y zonas de uso común.

117 Decreto de Aragón 69/1997 -art. 7.1.1-; Decreto de Extremadura 120/1998 -art. 11.A)-. El Decreto 253/1994 Comunidad Valenciana -art. 8.1- exige calefacción en habitaciones, cuartos de baño y zonas de uso común.

118 El Decreto de Aragón 69/1997 -art. 7.1.1- fija una baño por cada seis plazas o fracción. El Decreto 253/1994 Comunidad Valenciana -art. 8.1- exige un aseo por cada cuatro plazas más. El Decreto de Extremadura 120/1998 -art. 11.A)- exige un baño completo por cada cuatro plazas de alojamiento o fracción.

119 Decreto 253/1994 Comunidad Valenciana -art. 4.1-; Decreto de Extremadura 120/1998 -art. 11.A)-. El Decreto de Aragón 69/1997 -art. 7.1.1- exige un botiquín de auxilio en las viviendas aisladas.

120 Decreto 253/1994 Comunidad Valenciana -art. 4.1-; Decreto de Extremadura 120/1998 -art. 11.A)-. El Decreto de Aragón 69/1997 -art. 7.1.1- exige un servicio telefónico en las viviendas aisladas.

${ }^{121}$ Decreto 253/1994 Comunidad Valenciana -art. 8.2-; Decreto de Extremadura 120/1998 -art. 7.1-. El Decreto de Aragón 69/1997 -art. 7.1- admite que la ventilación pueda proceder de un patio no cubierto.

122 Decreto 253/1994 Comunidad Valenciana -art. 4.1-; Decreto de Extremadura 120/1998 -art. 11.A). 
$\operatorname{cendios}^{123}$; información sobre recursos turísticos de la zona en la que se encuentre ubicado $^{124}$; lencería de baño y cama adecuada al número de huéspedes de la vivienda ${ }^{125}$. Otras prescripciones son más particulares.

En todo caso, es frecuente que las normas contemplen dispensas para excepcionar del cumplimiento de las prescripciones técnicas a algunos establecimientos, posibilidad que debería ceñirse a aquellos establecimientos de valor histórico, sin que deba extenderse al resto ${ }^{126}$. Así, en Andalucía, el derogado Decreto 94/1995 de Casas Rurales contempló la dispensa "con criterio compensador en el cumplimiento de los requisitos señalados y, especialmente, en viviendas rurales caracterizadas por su singularidad arquitectónica y en aquellas donde el servicio turístico tenga la consideración de actividad complementaria”. Por su parte, el Decreto 20/2002 -art. 14- establece que la Administración podrá, mediante resolución motivada y previo informe técnico, "dispensar excepcionalmente a los alojamientos turísticos en el medio rural el cumplimiento de alguna o algunas prescripciones específicas en atención a las características físicas y arquitectónicas del edificio, especialmente en aquellos donde el servicio turístico tenga la consideración de actividad complementaria de la actividad agraria, y a la calidad ambiental del entorno"127. Además, el

123 Decreto 253/1994 Comunidad Valenciana -art. 4.1-; Decreto de Extremadura 120/1998 -art. 11.A).

124 Decreto 253/1994 Comunidad Valenciana -art. 4.1-; Decreto de Extremadura 120/1998 -art. 11.A). En cambio, este servicio es configurado en el Decreto de Andalucía 20/2002 -art. 13como un servicio complementario, esto es de prestación opcional por el titular del establecimiento.

125 Decreto de Aragón 69/1997 -art. 7.1-; Decreto de Extremadura 120/1998 -art. 11.A)-, Decreto de Andalucía 20/2002 -art. 12.1-.

126 El Decreto 253/1994 Comunidad Valenciana -art. 14.1- dispone que la Administración autonómica podrá dispensar del cumplimiento de alguno de los requisitos "cuando así lo justifique o aconseje la calidad general de las instalaciones o servicios". Asimismo, el Decreto de Aragón 69/1997 -art. 17- dispone que la Administración autonómica cuando circunstancias objetivas así lo aconsejen podrá, excepcionalmente, dispensar del cumplimiento de algunos de los requisitos exigidos en la norma, mediante resolución motivada previo informe de los servicios técnicos. Por su parte, el Decreto de Galicia -art. 56- prevé que la Administración podrá conceder las dispensas que razonablemente se soliciten en relación con las instalaciones y equipamientos. Por último, el Decreto Foral 243/1999 -art. 43- establece que la dispensa de alguna exigencia de escasa relevancia deberá basarse en criterios de compensación respecto del total de servicios y condiciones existentes.

127 La redacción del precepto es muy similar a la del art. 5 del Decreto de la Junta de Extremadura 120/1998, de ordenación del alojamiento en el medio rural, según el cual excepcionalmente la Consejería titular de las competencias en materia de turismo, previo informe técnico, 
Decreto 20/2002 -art. 10.2- admite que la especialización de los establecimientos de alojamiento turístico en el medio rural "podrá conllevar la dispensa de alguna de las especificaciones establecidas en la normativa aplicable. Esta circunstancia deberá hacerse constar expresamente en la publicidad del establecimiento turístico"128.

\subsection{Condiciones generales de prestación de los servicios}

-Períodos de apertura. La mayoría de las normas autonómicas imponen un período mínimo apertura del establecimiento al año, que es muy variado: desde los cuatro a los ocho meses ${ }^{129}$. En general, este tipo de requisitos impuestos por normas reglamentarias son de dudosa legalidad. En cualquier caso, el ordenamiento andaluz no contiene tal exigencia, ni en el anterior Decreto 94/1995 ni en el actual Decreto 20/2002.

-Duración máxima de estancia. Es común también en la legislación autonómica fijar plazos máximos de duración de cada estancia en el establecimiento alojativo, con objeto evidente de evitar que bajo la denominación de establecimiento turístico se encubra una mera relación de alquiler. Los plazos máximos más extendidos son 90 (Aragón, Asturias, Castilla y León y Cataluña ${ }^{130}$ ), y 60 días consecutivos (Galicia, Extrema-

podrá dispensar del cumplimiento de alguna o algunas de las prescripciones técnicas o exigencias requeridas, "en atención a las particulares circunstancias, convenientemente valoradas, cuando el cumplimiento de las mismas resulte incompatible con la preservación de la fisonomía, configuración tradicional del edificio, o con el desarrollo de la actividad", inciso éste último cuestionable.

${ }^{128}$ La propia Ley de Andalucía 12/1999 -art. 31.2-, al regular la clasificación administrativa de los establecimientos turísticos prevé que, excepcionalmente, mediante resolución motivada y previo informe técnico, la Consejería competente en la materia podrá dispensar del cumplimiento de algunos de los requisitos exigidos para otorgar una determinada clasificación a un establecimiento turístico.

129 Cuatro meses: Decreto de Aragón 69/1997 -art. 6.1-. Seis meses: Decreto de Asturias 26/1991 -art. 5-. Siete meses: Decreto de Extremadura 120/1998 -art. 15-, el cual precisa varios meses de oferta obligatoria -abril, mayo, junio, septiembre y octubre-. Ocho meses: Decreto de Castilla y León 84/1995 -art. 8-, que elevó el período mínimo de seis meses fijado en la Orden de 5 de mayo de 1989; Decreto de Castilla-La Mancha 43/1994 -art. 3-; Decreto de La Rioja 26/2000 -art. 15-; Decreto de Galicia 191/2004 -art. 19.1-, el cual redujo el período de once meses al año que había establecido la Orden de 2-1-1995.

${ }^{130}$ Decreto de Castilla y León 84/1995 -art. 8-; Decreto de Aragón 69/1997 -art. 6.2-; Decreto de Canarias 18/1998 -art. 7-; Decreto de Extremadura 120/1998 -art. 14-. 
dura) ${ }^{131}$. En el ordenamiento andaluz, nuevamente, no se impone restricción alguna.

-Servicios mínimos y complementarios. En general, las normas autonómicas establecen que las casas rurales "podrán" ofrecer otros servicios complementarios para uso exclusivo de los ocupantes del alojamiento ${ }^{132}$. Según el Decreto 20/2002 -art. 12.1- los alojamientos turísticos en el medio rural prestarán como mínimo el servicio de limpieza de habitaciones y cambio de lencería de cama y baño a la entrada de nuevos turistas ${ }^{133}$. Asimismo, el propio Decreto 20/2002 -art. 13- añade que los "establecimientos turísticos en el medio rural" "podrán" ofertar como servicios complementarios los siguientes: comidas y bebidas, custodia de valores, lavandería, venta de productos artesanales y gastronómicos propios de la comarca, información referente a los recursos turísticos de la comarca, actividades de turismo activo y otros servicios complementarios vinculados con el medio rural ${ }^{134}$. Por lo demás, aunque ya no se recoge el precepto contenido en el antiguo Decreto 94/1995, según el cual estos servicios se entendían exclusivamente dirigidos a los ocupantes del alojamiento, parece que tal regla va implícita en su naturaleza de servicios complementarios, de tal modo que su prestación a personas ajenas al alojamiento habrá de someterse a la normativa reguladora de la respectiva actividad ${ }^{135}$. En todo caso, desde un punto de vista empresarial, es evidente la conveniencia de ofertar al cliente todo el producto turístico -turismo activo, de naturaleza...- en una casa.

131 Decreto de Extremadura 120/1998 -art. 17-; Decreto de Galicia 191/2004 -art. 19.2-. Por su parte, el Decreto de la Región de Murcia 79/1992 -art. 6- establece que la duración máxima del alojamiento será de 15 días.

132 Decreto de Castilla-La Mancha 43/1994 -art. 6-; Decreto de Castilla y León 84/1995 -art. 9-.

133 Por su parte, el Decreto de Extremadura 120/1998 -art. 13.5-dispone que la limpieza diaria de la estancia será por cuenta del titular del establecimiento, salvo acuerdo en contrario suscrito por las partes interesadas, del que quedará constancia.

134 De modo similar, Decreto de Extremadura 120/1998 -art. 14-.

135 De un modo más radical, el Decreto de Castilla-La Mancha 43/1994 -art. 6- establece que la prestación de servicios de comidas y bebidas a personas no alojadas será considerada como actividad de restauración clandestina, pudiendo procederse a la clausura de las instalaciones en que se realice. 
-Responsable. Como en cualquier establecimiento turístico, los titulares del mismo son responsables de la adecuada calidad en la prestación de los servicios, la cual se realizará de forma directa y personal por los mismos o bien mediante personal cualificado para dicha función. Pero dado la peculiaridad de las Casas Rurales, su posible contratación íntegra y su eventual ubicación aislada, algunas normas se cuidan de precisar que el titular o persona delegada deberá estar localizable durante las 24 horas del día para solucionar los posibles problemas que pudieran plantearse en el alojamiento y deberá tener previstas las actuaciones que garanticen la pronta atención médica de los clientes que la pudieran necesitar -p. j., el desplazamiento urgente a un centro asistencial- ${ }^{136}$. No obstante, se trata de una regla que omite el Decreto 20/2002.

-Mobiliario y equipamiento. En los casos de casas rurales en régimen de contratación íntegra, alguna norma prevé que deberá presentarse a la llegada del cliente al establecimiento un inventario con los muebles y enseres y su estado de conservación y utilización, pudiendo el cliente verificar su exactitud, y entendiéndose que acepta las condiciones reflejadas en el mismo si en el momento de la firma no formula objeción ${ }^{137}$. Regla de nuevo omitida por el Decreto 20/2002.

-Higiene y limpieza. En general, en caso de contratación por habitaciones individualizadas, el arreglo y limpieza de las mismas y de los respectivos cuatros de baño se hará diariamente por el titular del establecimiento. Tratándose de contratación íntegra de la Casa Rural, el titular hará entrega de la misma al cliente en las condiciones de ocupación, junto con los útiles y productos básicos de limpieza que correrá de cuenta y cargo del usuario mientras se mantenga la ocupación, salvo que, previo acuerdo económico, se obligue a tal cometido de arreglo y limpieza del establecimiento el titular ${ }^{138}$. En este sentido, el Decreto de Andalucía 20/2002 -art. 12.2- ordena que los servicios mínimos que se prestarán en los "alojamientos turísticos en el medio rural" serán el de alojamiento y el de limpieza de habitaciones y cambio de lencería de cama y baño a la entrada de nuevos turistas.

\footnotetext{
${ }^{136}$ Decreto de Extremadura 120/1998 -art. 29-.

137 Decreto de Extremadura 120/1998 -art. 13.3-.

${ }^{138}$ Decreto de Extremadura 120/1998 -art. 31-.
} 
-Normas de régimen interior. Dado que las casas rurales tienen la consideración de establecimientos públicos -art. 36.1.e) en relación con el art. 24.b)-, el titular de cada establecimiento podrá acordar normas de régimen interior sobre uso de los servicios e instalaciones, los cuales deberá ser aprobados y diligenciados por la Administración ${ }^{139}$.

-Distintivos y señalización. Todas las normas del sector establecen un sistema de placas o distintivos identificativos ${ }^{140}$. En este sentido, el Decreto 20/2002 -art. 35.1- dispone que todos los establecimientos destinados al turismo en el medio rural, así como las viviendas turísticas de alojamiento rural, deberán exhibir en la parte exterior y junto a la entrada principal una placa identificativa sobre el tipo de alojamiento y, en su caso, su categoría y especialización. Además, en lugar visible del establecimiento y en toda la publicidad y documentación del mismo deberán expresarse los datos de inscripción en el Registro de Turismo de Andalucía -fecha, número, categoría y especialización-141.

\subsection{Régimen administrativo}

Dado que las normas imponen unos requisitos y exigencias, tanto materiales como funcionales, para el funcionamiento de estos establecimientos, en coherencia, deben contemplarse los instrumentos o técnicas que permitan a la Administración intervenir para controlar el efectivo cumplimiento de los mismos. El instrumento mínimo es, desde luego, la función inspectora que puede recaer con carácter previo al funcionamiento del establecimiento o en cualquier momento posterior al mismo. Pero, sobre todo, se trata de determinar si, además, va a ordenarse un control preventivo de carácter preceptivo. A este respecto, el criterio más extendido consiste en someter a autorización administrativa previa el funcionamiento de los establecimientos de alojamiento turístico en general, y de los de turismo rural en particular ${ }^{142}$. Asimismo, el

${ }^{139}$ Así, lo prevé expresamente el art. 32 del Decreto de Extremadura 120/1998.

${ }^{140}$ Decreto de Extremadura 120/1998 -art. 38-.

${ }^{141}$ Por Orden de la Consejería de Turismo y Deporte de 19 de septiembre de 2003, se aprobaron los distintivos de los alojamientos turísticos en el medio rural. Sin embargo, un años después sólo una veintena de establecimientos había recibido la "Q" que simboliza la máxima distinción. El País, 12.9.2004.

142 Ley del País Vasco 6/1994 -art. 8.1-; Decreto de Castilla-La Mancha 43/1994 -art. 14-; Ley de Canarias 7/1995 -art. 13-; Ley de Extremadura 2/1997 -art. 13- y Decreto de Extremadura 120/1998 -art. 35-; Ley de Galicia 9/1997 -art. 16.1-; Ley de La Rioja 2/2001 -art. 8-; Ley de As- 
plazo más común es de tres meses y el sentido del silencio administrativo más extendido es el estimatorio ${ }^{143}$.

En el caso andaluz, la Ley 12/1999 -art. 35.2- optó por sustituir a la autorización previa por la preceptiva inscripción en el Registro, en principio para aparentar un menor intervencionismo administrativo ${ }^{144}$. Se mantiene así el criterio del Decreto 94/1995 de Casas Rurales, que creó en el Registro una sección para las Casas Rurales. Por el contrario, para las viviendas turísticas de alojamiento rural la propia Ley 12/1999 -art. 34.2- establece que los titulares de las mismas deben "comunicar" el ejercicio de su actividad con carácter previo al Registro de Turismo. Es decir, se sustituye el deber de inscripción por un deber de comunicación previa. De este modo, se viene a mantener el régimen establecido para las viviendas turísticas vacacionales en el Real Decreto de 15 de octubre de 1982, que sólo obligó a notificar al organismo competente su dedicación al tráfico turístico -art. 18-.

Ahora bien, dado que la inscripción ordenada en la Ley 12/1999 para los establecimientos de alojamiento turístico tiene un carácter constitutivo, de modo que el ejercicio de la actividad turística sin contar con la inscripción constituye una actividad clandestina y, por tanto, ilegal -arts. 35, 28.3 y 60.1 Ley 12/1999-, la inscripción viene a funcionar, materialmente, como una autorización previa, pues constituye título habilitante para el ejercicio lícito de la actividad $^{145}$. Es decir, independientemente de la semántica, la finalidad y los efectos de esta inscripción son equivalentes a los de una autorización previa. Más aún, en aplicación del cuestionable criterio seguido por la Ley de Anda-

turias 7/2001 -art.25-; Decreto de Aragón 69/1997 -art. 13-; Decreto de Canarias 18/1998 -art. 10-. Igualmente, aunque el Decreto de la Comunidad Valenciana 253/1994 -art. 12.1- habla de solicitud de "declaración", funciona como una solicitud de autorización.

${ }^{143}$ Así, tanto el Decreto Comunidad Valenciana 253/1994 -art. 12.2-, como el Decreto de Aragón 69/1997 -art. 14- fijan un plazo de tres meses para la resolución y un régimen de silencio estimatorio. Más aún, el Decreto de Canarias 18/1998 -art. 11- fija un plazo de dos meses y un sentido estimatorio del silencio. Asimismo, tanto el Decreto de La Rioja 26/2000 -art. 8- como el Decreto de Galicia 191/2004 -art. 55.2- fijan un plazo de seis meses y un sentido estimatorio del silencio. Por su parte, el Decreto de Extremadura 120/1998 -art. 35.2- si bien fija un plazo de tres meses, el sentido del silencio es desestimatorio.

${ }^{144}$ Este es también el criterio de la Ley de Cataluña 13/2002 -art. 49.2-.

${ }^{145}$ Véase la STSJ Andalucía (Sala de Málaga) de 29 de enero de 2004 (JUR 2004\70916) de imposición de una sanción grave a un establecimiento de alojamiento turístico por falta de inscripción en el registro. 
lucía 12/1999 -disp. adic. 6 a $^{\text {-, }}$, según el cual en caso de silencio administrativo deben entenderse desestimadas las solicitudes de inscripción en el Registro de Turismo, se produce un retroceso en relación con la ordenación del Decreto de 94/1995, el cual contemplaba un plazo de un mes y un silencio administrativo estimatorio $^{146}$. De este modo, el grado efectivo de intervencionismo establecido es también mayor que en aquellas Comunidades Autónomas en las que se establece un sistema de autorización combinado con un silencio administrativo estimatorio.

A nuestro modo de ver, si ya existía un alto grado de funcionamiento de casas rurales al margen del Registro, a pesar de que el régimen administrativo del Decreto 94/1995 era menos oneroso, cabe pensar que dicho fenómeno de actividad turística al margen de los cauces oficiales lejos de encauzarse se va acentuar con las normas más intervencionistas del Decreto 20/2002 ${ }^{147}$. Sobre todo si al régimen administrativo indicado se añade la dúctil distinción que existe a partir del Decreto 20/2002 entre casas rurales -sometidas a inscripción obligatoria- $\mathrm{y}$ viviendas turísticas de alojamiento rural -sujetas al régimen de comunicación previa- ${ }^{148}$.

\subsection{Otras modalidades de establecimientos alojativos rurales.}

La tipología de establecimientos de alojamiento de turismo rural es extraordinariamente diversa en las distintas Comunidades Autónomas ${ }^{149}$. En el

${ }^{146}$ El Decreto 20/2002 no regula los aspectos referentes al procedimiento de inscripción de los establecimientos de alojamiento turístico en el medio rural, sino que se limita a recordar el deber legal de inscripción en el Registro de Turismo -art. 9.3-, por lo que parece remitirse a lo que establezca el Reglamento que ordene el Registro de Turismo de Andalucía -tal como se desprende de la disposición transitoria tercera-. Por su parte, el Decreto 47/2004, de 10 de febrero, de establecimientos hoteleros, aun cuando contiene una regulación completa del procedimiento de inscripción, únicamente se aplica a los establecimientos hoteleros -art. 1-, incluidos los rurales, pero no al resto de establecimientos de alojamiento turístico. En todo caso, este Decreto mantiene el criterio del silencio desestimatorio, tanto para la inscripción provisional como definitiva -arts. 52 y 55-.

${ }^{147}$ La Administración turística reconoció en marzo del 2001 que sólo un 20\% de los establecimientos que operan en el sector estaban registrados oficialmente. El País, 11.3.2001. Y es muy posible que los cifras de "paralegalidad" sean aún más altas que las reconocidas por la Administración. Así en comarcas como los parques naturales de Grazalema y Cazorla y en las Alpujarras se estima que la oferta no reglada de alojamientos rural llega a superar a la regularizada. El País, 12.9.2004.

148 Por lo demás, la disposición transitoria $3^{\underline{a}}$ del Decreto 20/2002 determina las especificaciones que ha de contener la comunicación previa, hasta tanto se la regulación de Registro de Turismo de Andalucía.

${ }^{149}$ Así, p. j., la Ley de Baleares 2/1999 -art. 26- tipifica el establecimiento de Turismo interior, entendiendo por tal la vivienda en la que se preste servicio de alojamiento, construida con ante- 
ordenamiento andaluz, junto a las Casas Rurales y las Viviendas Turísticas de Alojamiento Rural ya tratadas, el Decreto 20/2002 contempla también a los establecimientos hoteleros y apartamentos turísticos rurales, los complejos turísticos rurales y "demás establecimientos turísticos cuya normativa específica así lo determine", entre los cuales habrá que incluir a los campamentos de turismo rural, de acuerdo con lo establecido en el Decreto 164/2003, de 17 de junio, de ordenación de campamentos de turismo.

\subsubsection{El Hotel rural.}

En algunas Comunidades Autónomas la noción de hotel rural se vincula a un establecimiento ubicado (en el medio rural) en inmuebles de singular valor arquitectónico o, al menos, que responden a la arquitectura tradicional de la zona, y con un número limitado de plazas, que varía según los $\operatorname{casos}^{150}$.

En el ordenamiento andaluz, al considerarse el turismo rural como un destino genérico, los hoteles rurales se configuran en el Decreto 47/2004 como una simple modalidad de los establecimientos hoteleros -junto a los de playa, ciudad y carretera-. Por su parte, el Decreto 20/2002 -art. 17.1- establece los requisitos siguientes para los establecimientos hoteleros en el medio rural:

a) Estar constituidos por una sola edificación, aunque pueden contar con unidades anejas independientes.

b) No superar las tres plantas, sin que a estos efectos se contabilicen las zonas abuhardilladas y de trasteros ${ }^{151}$.

rioridad a una fecha determinada, situada en el casco antiguo de los núcleos urbanos a una distancia mínima de 500 metros de la zona turística más próxima. Este edificio debe tener la tipología tradicional del entorno urbano en que se ubique, y constituir una sola vivienda, con un número de plazas limitado.

15025 plazas en la Ley de Baleares 2/1999 -art. 25-; o 36 plazas en la Ley de Asturias 7/2001 -art. 38.2-; 40 plazas en el Decreto del País Vasco 128/1996 -art. 3-. De otro lado, el Decreto de Canarias 18/1998 -art. 4- establece que la capacidad alojativa de los hoteles rurales no debe superar 20 habitaciones dobles o individuales. Y el Decreto de Extremadura 120/1998 -art. 43- fija un máximo de 30 habitaciones y 60 plazas. Por su parte, la Ley de Aragón 6/2003 -art. 42.1- establece que los hoteles rurales tendrán un número máximo de plazas de alojamiento, "que se determinará reglamentariamente".

${ }^{151} \mathrm{Si}$ bien estas zonas no deben superar un 25\% de la ocupación de esa planta. En cambio, en el Decreto de Extremadura 120/1998 -art. 43- se exige que la edificación no supere las dos plantas, salvo que el edificio original presente otra estructura. 
c) Adecuarse a las características constructivas propias de la comarca. En realidad, se trata de una reiteración de la exigencia general contenida en el art. 9 del Decreto.

d) Su capacidad alojativa no debe ser inferior a 21 plazas. Se trata éste de un factor diferenciador con las casas rurales, pues debe recordarse que el Decreto sitúa en 20 plazas la capacidad máxima de las casas rurales. De otro lado, la ausencia de una capacidad máxima -existente en otras Comunidades Autónomas, según se dijo- desdibuja la imagen común del turismo rural antes señalada y no es acorde con los criterios consensuados en el sector ${ }^{152}$.

e) Servicios o actividades complementarias vinculados con el entorno rural. Se trata de una exigencia que, sin embargo, se compadece mal con la economía del Decreto, pues de los arts. 12 y 13 parece desprenderse que estos servicios complementarios tienen un carácter opcional, no obligado. En cambio, se echan en falta prescripciones contenidas en otras normas autonómicas, en el sentido, por ejemplo, de que una parte de la carta platos y vinos ofertados sean típicos de la zona ${ }^{153}$. Curiosamente, el Decreto sí impone un requisito similar a los complejos de turismo rural, los cuales deben ofrecer el de restauración con gastronomía tradicional de la comarca en la que se ubiquen.

f) Estar dotados de zonas ajardinadas o patio interior, salvo aquéllos que estén ubicados en el núcleo principal de población.

De otro lado, en el caso de que el establecimiento se ubique en suelo no urbanizable, el Decreto 47/2004 -art. 37- impone unos requisitos adicionales ${ }^{154}$. Asimismo, este Decreto 47/2004 -Anexo 6- prevé varias especialidades de establecimientos hoteleros rurales: albergues, establecimientos hoteleros de montaña y establecimientos hoteleros de naturaleza. Con todo, debe señalarse que los establecimientos hoteleros rurales están sometidos a las prescripciones generales ordenadas en el Decreto 47/2004.

152 El Ágora Internacional de Turismo Rural, celebrado en Jaén en octubre 2004, señaló que los establecimientos alojativos de turismo rural no debían de exceder de 40 plazas.

${ }^{153}$ Decreto de Extremadura 120/1998 -art. 46.5-.

${ }^{154}$ La unidad parcelaria apta para la edificación deberá tener una superficie no inferior al resultado, en metros cuadrados, de multiplicar por 300 el número de unidades alojativas, con un mínimo de 30.000 metros cuadrados; y la actuación, en su conjunto, tenderá que contribuir a la conservación, mejora o regeneración de los valores territoriales, agrícolas, naturales, paisajísticos o patrimoniales existentes en el ámbito de su localización. No se trata, sin embargo, de una extensión excesiva, pues, p. j., en las Islas Baleares se ordena una parcela con una extensión mínima de 50.000 metros cuadrados (Decreto 62/1995 -art. 3-). 


\subsubsection{Los Complejos turísticos rurales.}

Con esta denominación u otras, como centros de Turismo Rural ${ }^{155}$ o Villas vacacionales ${ }^{156} \mathrm{o}$ aldeas de turismo rural ${ }^{157}$, se hace referencia a aquellos recintos integrados por una serie de inmuebles, cuya situación, instalaciones y servicios permitan a los usuarios, bajo fórmulas previamente determinadas, el disfrute de su estancia en contacto directo con la naturaleza, facilitándoles, mediante precio, hospedaje junto con la posibilidad de practicar deportes y participar en actividades colectivas, de carácter cultural, cinegético, didácticas, lúdicas, etc. Por ello, la oferta de servicios complementarios de ocio y tiempo libre puede considerarse como un elemento característico de estos establecimientos.

Por su parte, el Decreto 20/2002 -art. 18.1- establece los requisitos siguientes para los complejos turísticos rurales:

a) Estar compuesto por un conjunto de inmuebles que, constituyendo una unidad de explotación, tenga una capacidad no inferior a 21 plazas en su conjunto y un máximo de 250 plazas. De este modo, al igual que los hoteles rurales, se parte del límite máximo fijado a las casas rurales ${ }^{158}$.

b) No superar cada inmueble una capacidad máxima de alojamiento de 20 plazas, que coincide con el indicado para las casas rurales y viviendas turísticas de alojamiento rural.

c) No superar los inmuebles de alojamiento las dos plantas, salvo en el caso del edificio de servicios comunes, que podrá contar una tercera planta.

d) Estar dotados de zonas verdes comunes.

e) Además de los servicios mínimos a prestar en todos los alojamientos turísticos en el medio rural, los complejos turísticos rurales deben ofrecer el de restauración con gastronomía tradicional de la comarca en la que se ubiquen -art. 12.2-. De este modo, llama la atención la no exigencia de una oferta de actividades de ocio y tiempo libre o,

\footnotetext{
${ }^{155}$ Ley de Castilla y León 10/1997 -art. 26- y Decreto 84/1995 -art. 11-.

${ }^{156}$ Ley de Extremadura 2/1997 -art. 31-.

${ }^{157}$ Decreto de Galicia 191/2004 -art. 4-.

158 Debe señalarse que, p. j., en el Decreto de Castilla y León 84/1995 -art. 11- se fija un máximo de 60 plazas para los centros de turismo rural.
} 
al menos, la disposición de instalaciones deportivas y de esparcimiento, que es -como se ha dicho- lo característico de este tipo de establecimientos turísticos ${ }^{159}$. Curiosamente, el Decreto sí viene a exigir, como se ha dicho antes, servicios complementarios vinculados al medio ambiente a los hoteles rurales, lo cual constituye una exigencia insólita en esta modalidad de establecimiento. En cambio, se exige una oferta de restauración con gastronomía tradicional, requisito más propio de un hotel rural.

Por su parte, la Junta de Andalucía ha venido contando con una red propia de Villas Turísticas, a la que da carta de naturaleza el Decreto 20/2002 -art. 18.2- al establecer que los complejos turísticos rurales propiedad de la Administración de la Junta de Andalucía se denominarán Villas Turísticas ${ }^{160}$. Asimismo, se crea la Red Andaluza de Villas Turísticas, la cual está constituida por el conjunto de complejos turísticos rurales de titularidad de la Administración de la Junta de Andalucía, con independencia de que sea explotados directa o indirectamente -disposición adicional $2^{2}-{ }^{161}$. De otro lado, debe señalarse que la Ley 12/1999 -art. 40.4- excluyó expresamente de su ámbito de aplicación a los centros, colonias escolares y establecimientos similares.

\subsubsection{Los campamentos de turismo rural.}

Anticipándose al Decreto 47/2004 de establecimientos hoteleros, el Decreto 164/2003 de campamentos de turismo clasificó los campamentos de turismo en varias modalidades genéricas en relación con la ubicación de sus instalaciones, incluyendo entre ellas la rural. Por ello, los campamentos de turis-

159 En este sentido, p. j., Decreto de Castilla y León 84/1995 -art. 11-; Decreto de Galicia 191/2004 -art. 4-, en relación con las aldeas de turismo rural.

160 Asimismo, las Villas Turísticas propiedad de la Junta de Andalucía están excluidas de la Orden de 19 de septiembre de 2003 sobre distintivos turísticos en el medio rural -art. 1-. En realidad, la creación de las Villas Turísticas se remonta a mediados de la década de los años 80 , en el marco de los Programas de Desarrollo Integrado del Turismo Rural (PRODINTUR) llevados a cabo por la Junta de Andalucía, con el objetivo de servir de estímulo al sector privado. La gestión de las Villas Turísticas se realiza mediante concesión administrativa previo concurso público, salvo en algún caso donde se han llegado a convenio con la Diputación Provincial (caso de Grazalema en Cádiz).

161 No puede dejar de indicarse que se trata de un criterio convencional. Así, p. j., la Ley de Extremadura 2/1997 incluye entre los alojamientos turísticos extrahoteleros a los centros, colonias escolares y similares "en cuanto sus actividades tengan incidencia o trascendencia turística" -art. 20.1-. 
mo rural no presentan particularidades dignas de mención en cuanto a su régimen jurídico, estando sometidos al conjunto de prescripciones ordenadas en el Decreto 164/2003. Únicamente señalar la especialidad de Campamentos-Cortijo - disposición adicional $2^{\mathfrak{a}}$-, en el sentido de campamentos ubicados en comarcas rurales del interior que se encuentran anejos a cortijos y cuyos acampados participen de la vida y ambiente de los mismos sin interferir en los trabajos propios de éstos ${ }^{162}$.

\section{OTRAS ACTIVIDADES Y SERVICIOS TURÍSTICOS COMPLE- MENTARIOS}

\subsection{Los Establecimientos de Restauración}

La gastronomía tradicional constituye uno de los principales elementos identificadores y diferenciadores de la oferta turística rural frente a la urbana, y puede constatarse que en algunas Comunidades Autónomas, como la andaluza, a pesar de la riqueza de su "patrimonio gastronómico", este factor apenas se ha incorporado a su oferta como atractivo turístico adicional. Con objeto de promover una oferta gastronómica de calidad diferenciada y propia del medio rural, desde algunas Comunidades Autónomas se viene impulsando un distintivo de calidad, como instrumento promocional de la oferta de restauración de mayor cualificación y reservado al segmento de mayor calidad de la oferta restauradora en ámbitos rurales.

En este sentido, en Andalucía, el Plan Senda propuso la denominación "Mesón Rural", que ha sido adoptada por el Decreto 20/2002. Según esta norma -art. 20.2-, tendrán la consideración de establecimientos turísticos de restauración en el medio rural con la denominación de "Mesón rural" aquellos establecimientos de restauración que, además de cumplir los requisitos generales ordenados en la normativa de establecimientos de restauración, ostenten, al menos cuatro de los siguientes criterios ${ }^{163}$ :

\footnotetext{
162 De otro lado, los campamentos de turismo que sean clasificados en la modalidad rural están sujetos a la Orden de 19 de septiembre de 2003 sobre distintivos turísticos en el medio rural -art. 1-.

163 El distintivo de la denominación "Mesón Rural" fue aprobado por la Orden de 19 de septiembre de 2003 sobre distintivos turísticos en el medio rural -art. 1-. En este sentido, J. TUDELA ARANDA, "Hacia el desarrollo de un concepto integral de turismo rural. Especial referencia a la Comunidad Autónoma de Aragón”, op. cit., ha llamado la atención sobre la oportunidad de crear marcas de calidad en materia de restauración en el medio rural.
} 
a) Que se trate de un edificio tradicional o que, sin serlo, se adecue a las características arquitectónicas tradicionales de la comarca donde se encuentra ubicado.

b) Que la decoración, mobiliario, vajilla y demás elementos sea adecuada a los modelos tradicionales de la comarca.

c) Que la carta incorpore la gastronomía tradicional de la zona.

d) Que utilice preferentemente productos locales, comarcales o andaluces en general, en la preparación de las comidas.

e) Que utilice alimentos de producción integrada o agricultura ecológica.

f) Que facilite información a los clientes, tanto sobre los productos y recetas como de la comarca donde se encuentre ubicado el establecimiento.

De otro lado, es también preciso que la Administración competente en materia turística impulse, en coordinación con las demás Administraciones competentes, la cualificación y formación de los profesionales de la restauración, así como potenciar la investigación en la recuperación de la gastronomía tradicional (Decreto 20/2002 -art. 38.3-).

\subsection{La comercialización de los servicios turísticos rurales: las centrales de re- servas}

La oferta de turismo rural se ha venido caracterizando por su dispersión -debido en gran medida a ubicación en el medio rural-y por una capacidad muy reducida -limitación del número de plazas-, caracteres éstos derivados -como nos consta- de las propias normas del sector. Esta circunstancia ha originado un menor interés comercial por parte de las agencias de viajes en promocionar esta modalidad turística, y si a ello se une el carácter casi artesanal de la promoción en este sector, ello ha determinado que la comercialización constituya uno de los puntos débiles de turismo rural, como demuestra el hecho de que se calcula que aproximadamente el $90 \%$ de los clientes contratan directamente sus servicios con los establecimientos alojativos, y que sigue predominando la demanda nacional y regional en este ámbito ${ }^{164}$. Por ello, es innegable la necesidad de promover un sistema competitivo que permita el acceso a mercados exteriores, así como una gestión menos dispersa que, entre

\footnotetext{
${ }^{164}$ Según el estudio sobre la demanda en turismo rural elaborado por el CSIC en 1994, el porcentaje de viajes al espacio rural andaluz organizado por cuenta propia era del 93,5\%, en comparación con el 63,5\% de los que lo hacen para el conjunto de Andalucía.
} 
otros beneficios, permita derivar el exceso de demanda sobre una zona a otras zonas distintas, optimizando los resultados del turismo rural.

Debido a esta necesidad de una adecuada comercialización del turismo rural, han surgido en la práctica agentes novedosos, no previstos en la legislación, como es el caso de las "centrales de reservas", como fórmulas de comercialización asociada y radicadas en los territorios de destino o receptores y, con frecuencia, auspiciadas por la propia Administración turística ${ }^{165}$. Y, aunque de un modo tímido, la legislación autonómica ha dado carta de naturaleza a esta figura, en algunos casos de un modo implícito ${ }^{166}$, y otros ya explícito ${ }^{167}$. En este sentido, en el ordenamiento andaluz, la Ley 12/1999 de Turismo -art. 47.4- incluyó expresamente a las centrales de reservas en la categoría de empresas de intermediación turística ${ }^{168}$. Así, en Andalucía, la Adminis-

165 En Andalucía destacan la Red Andaluza de Alojamientos Rurales (que agrupa aproximadamente a 400 establecimientos), la Rural Andalus (agencia mayorista) y los Centros de Iniciativas Turísticas creados por los parques naturales andaluces. En Aragón, la propia Administración turística impulsó, con el apoyo de la Confederación de Empresarios de la Hostelería, la llamada Central Única de Reservas. En Galicia puede citarse la Central de Reservas de Alojamientos de Turismo Rural de la Sociedad de Imagen y Promoción Turística de Galicia.

166 Así, la Ley de Castilla y León -art. 28- se refiere genéricamente a las "empresas de intermediación turística", si bien inmediatamente después se limita a regular a las agencias de viajes -art. 29-. Por su parte, la Ley de la Región de Murcia 11/1997 -art. 37-menciona, entre las llamadas Empresas de Actividades Turísticas Complementarias, a las "agrupaciones de empresas turísticas que tengan por objeto la comercialización común de ofertas turísticas, la centralización de reservas o, en general, la consecución de la mejora en la prestación de sus servicios", empresas a las que la Ley obliga a solicitar su inscripción en una Sección Especial de Empresas de Actividades Turísticas Complementarias. Y, de modo similar, la Ley de la Comunidad Valenciana 3/1998 -art. 5contempla, entre las empresas turísticas, junto a las agencias de viajes, a las de "comercialización intermediación, organización y prestación de cualesquiera servicios turísticos cuando éstos no constituyan el objeto propio de las actividades relacionadas en los puntos anteriores", si bien más

167 Así, la Ley de Galicia 9/1997, tras referirse en su art. 3, relativo a las empresas, establecimientos y actividades sujetas a la Ley, a las "Agencias de viajes y demás empresas de intermediación turística", menciona expresamente a las centrales de reserva junto a las Agencias de Viajes -art. 25.1-, a efectos de inscripción obligatoria en el Registro de Empresas y Actividades Turísticas, si bien después se limita a regular exclusivamente el régimen de las Agencias de Viajes -arts. 58 y ss.-. Y, sobre todo, las Leyes de La Rioja 2/2001 -art. 18.2-, de Asturias 7/2001 -art. 52.1-y de Aragón 6/2003 definen expresamente qué se entiende por centrales de reserva, remitiendo ésta última al desarrollo reglamentario las condiciones y requisitos exigibles para esta modalidad de intermediación.

168 Aun cuando la exposición de motivos del Decreto 20/2002 declara expresamente que la norma persigue fortalecer cauces de colaboración en lo relativo a la comercialización de la oferta turística, lo cierto es que en su articulado omite por completo la ordenación de la actividad de comercialización de los productos del turismo rural, tal vez por considerar que su ordenación debía llevarse a cabo en el Decreto relativo a la intermediación turística, como así efectivamente se hizo mediante el Decreto 301/2002. 
tración autonómica promueve desde la empresa pública Turismo Andaluz SA la llamada Central de Reservas Turísticas de Andalucía mediante el sistema Séneca que permite realizar reservas on line a través de internet.

El principal problema que plantea esta figura consiste en determinar su campo de actuación frente a las agencias de viajes. Como es sabido, la legislación vigente reserva a las Agencias de Viajes el ejercicio de las actividades de intermediación de servicios turísticos ${ }^{169}$, y ello es así debido a las exigencias legales cualificadas para ejercer dicha actividad -adopción de forma societaria, constitución de garantías para supuestos de insolvencia, seguros de responsabilidad civil... - ${ }^{170}$.

Ya antes de que las normas autonómicas dieran respaldo expreso a esta figura, la propia legislación estatal sobre agencias de viajes estableció que la reserva en favor de las Agencias de Viajes lo es "sin perjuicio de la facultad conferida por la legislación vigente a transportistas, hoteleros y otras empresas turísticas para contratar directamente con los clientes la prestación de sus propios servicios" ${ }^{171}$. E, independientemente del dato jurídico-positivo, debe entenderse que esta cláusula que permite a las empresas turísticas comercializar directamente sus propios productos y servicios constituye una facultad inherente al derecho constitucional a la libertad de empresa, principio recogido ex-

${ }^{169}$ Real Decreto 271/1988, de 25 de marzo, por el que se regula el ejercicio de las actividades propias de las Agencias de Viajes, así como Orden Ministerial de 14 de abril de 1988, que desarrolla el Real Decreto anterior y por la que se aprueban las normas reguladoras de las Agencias de Viajes, la cual establece que las personas físicas o jurídicas, instituciones, organismos y entidades de cualquier orden, tanto públicas como privadas, que oferten al público la realización de viajes (a lo que habría que añadir cualquiera otras de las actividades reservadas), habrán de hacerlo a través de una Agencia de Viajes legalmente constituida -art. 36-.

${ }^{170}$ En efecto, la reserva de actividades de intermediación a las Agencias de Viajes no es a un simple "nomen iuris", sino que la norma sujeta a estas empresas turísticas a una exigencias cualificadas -forma societaria, capital social mínimo, constitución de fianzas... - orientadas a garantizar del cumplimiento de las obligaciones derivadas de la prestación de sus servicios, obligaciones éstas que el Tribunal Supremo, sentencia de 16 de marzo de 1998 -RJ 199812846-, ha con reconocido -con matices- lícitas desde la perspectiva de protección de los derechos de los consumidores y usuarios, desestimando que tales exigencias supongan una quiebra del principio de igualdad.

${ }^{171}$ Real Decreto 271/1988 -art. 2.2-, cláusula ésta que ha permitido al Tribunal de Defensa de la Competencia, resolución de 11 de octubre de 1994 -expd. no 89/1994-, a desestimar las denuncias de competencia desleal en los casos de empresas turísticas que venden sus propios servicios. Y cláusulas similares se encuentran en la legislación autonómica, como la Ley de Cataluña 13/2002 -art. 53.2-. 
presamente en alguna Ley del sector ${ }^{172}$.Y es justamente en esta cláusula donde han encontrado acomodo las Centrales de Reserva, siempre que se trate de centrales promovidas por los propios titulares de los establecimientos y servicios turísticos.

Ahora bien, al menos en aquellas Comunidades Autónomas en las que se ha producido un reconocimiento legal expreso de la figura de la Central de Reservas unido a una delimitación de su ámbito de actuación, debe entenderse que estos agentes turísticos pueden ser creados por particulares (y Administraciones) que comercializan los servicios turísticos de terceros (ya sean los prestadores directos de los servicios turísticos o las propias agencias de viajes) a cambio de una comisión o de otro tipo de contraprestación. De este modo, la clave es determinar el ámbito funcional de las centrales de reservas.

A este respecto, la legislación autonómica más reciente viene a converger en el criterio según el cual se entiende por centrales de reserva las empresas turísticas que se dedican "exclusivamente" a reservar servicios turísticos ${ }^{173}$. Por su parte, en el ordenamiento andaluz, aun cuando la Ley 12/1999 no estableció dicha limitación, está contenida en el Decreto 301/2002, de 17 de diciembre, de agencias de viaje y centrales de reserva, de acuerdo con el cual las centrales de reserva pueden realizar exclusivamente las actividades de mediación en la reserva de plazas en alojamientos turísticos y la mediación en la contratación de otros servicios turísticos -art. $29.1-^{174}$, de tal modo que las agencias de viaje mantienen la exclusividad sobre las actividades de mediación en la venta de billetes y reserva de plazas en medios de transporte (pues el transporte de personas no es un servicio turístico), la organización o comercialización de viajes combinados y de excursiones de duración inferior a 24 horas ${ }^{175}$.

${ }^{172}$ Ley de Canarias 7/1995 -art. 13.1-.

173 Así Ley de Asturias 7/2001 -art. 52.1- y Ley de Aragón 6/2003 -art. 47.1-. Menos tajante, la Ley de La Rioja 2/2001 -art. 18.2- establece que las centrales de reserva son empresas y entidades que se dedican "principalmente" a reservar servicios turísticos de forma individualizada. Pero añade: "Las centrales de reserva no tendrán la capacidad para organizar viajes combinados, ni excursiones de un día”.

${ }^{174}$ A estas actividades, compartidas con las agencias de viajes, se añaden otras "complementarias", las actividades de información, difusión y venta de material publicitario relacionado con el turismo -art. 29.2-.

175 Como es sabido, la Ley 21/1995, de 6 de julio, reguladora de los viajes combinados, impone obligatoriamente la intervención de una Agencia de Viajes -disposición adicional segunda-. 
Asimismo, en el sentido antes referido de la central de reservas como intermediación asociada a los propios titulares de los establecimientos turísticos, la Ley 12/1999 -art. 47.4- contiene otra característica diferenciadora de las centrales de reserva, pues en ningún caso pueden percibir de los usuarios contraprestación económica por su intermediación ${ }^{176}$. De este modo, el contrato con el turista se formalizará bien directamente entre el titular del servicio turístico y el usuario final, o bien a través de una agencia de viajes, percibiendo la central de reservas, en uno y otro caso, la comisión correspondiente bien del prestador del servicio turístico bien de la agencia de viajes ${ }^{177}$.

En cuanto a su régimen jurídico, debe destacarse que, por coherencia legal, las centrales de reservas, al igual que las agencias de viaje, están obligadas a no comercializar servicios correspondientes a establecimientos en situación de clandestinidad, esto es que no se encuentren debidamente inscritos en el Registro de Turismo de Andalucía -art. 4 del Decreto 301/2002 en relación con el art. 35 de la Ley 12/1999-, lo cual supone una importante limitación, dada el escaso nivel de inscripción en el Registro de los establecimientos que de hecho operan en el sector. Por lo demás, las centrales de reservas, como sujetos turísticos que son independientemente de sus asociados, deben inscribirse con carácter previo al ejercicio de su actividad en el Registro administrativo de turismo -arts 34.1.c) y 35.1 de Ley 12/1999 y art. 31.1 del Decreto 301/2002-178.

Finalmente, puede señalarse que en alguna Comunidad Autónoma se establece un mecanismo expreso de creación de las centrales de reservas, en el sentido de que los titulares de Casas Rurales que hayan recibido subvenciones públicas están obligados a instalar y mantener, con la participación de todos

\footnotetext{
${ }^{176}$ En idéntico sentido, Ley de La Rioja 2/2001 -art. 18.2-. Y, en el ordenamiento andaluz, art. 2.1 del Decreto 301/2002.

177 Vid. A. AURIOLES MARTÍN, "Las centrales de reserva: su reconocimiento legal como empresas de intermediación turística en la Ley del Turismo de Andalucía", en VV. AA., Persona y Estado en el umbral del siglo XXI, XX Aniversario Facultad de Derecho de Málaga, 2001, pp. 85 y ss.; I. SÁNCHEZ RUIZ, "Las empresas de intemediación turística en la Ley del Turismo de Andalucía", en VV. AA., Derecho y Turismo, III Jornadas de Derecho Turístico, Consejería de Turismo y Deporte, Málaga, 2000, pp. 335 y ss.

178 De otro lado, el Decreto 301/2002 -art. 31.2- no impone a las centrales de reservas, a diferencia de las agencias de viajes, la suscripción de pólizas de seguro de responsabilidad civil, si bien las obliga a constituir una garantía que cubra su eventual declaración de responsabilidad como consecuencia del incumplimiento o cumplimiento defectuoso de sus obligaciones frente a los usuarios finales o empresas prestadoras de servicios turísticos -art. 30-.
} 
ellos, una Central de Información y Reservas, si bien los titulares de Casas Rurales que no hayan recibido tales beneficios podrán incorporarse a estas centrales con los mismos derechos y obligaciones que los anteriores ${ }^{179}$.

\subsection{Las medidas de promoción y fomento del turismo rural}

\subsubsection{Promoción del turismo rural}

Como es conocido, una de las claves de la política turística es la promoción del producto turístico, en este caso el turismo rural de cada Comunidad Autónoma, ante los mercados potenciales, nacionales y extranjeros. Una primera medida muy extendida consiste en la creación de un distintivo específico para aquellos servicios turísticos que se desarrollen en el medio rural y que cumplan los requisitos, o que hayan sido declarados con la especialidad de turismo en el medio rural -art. 41 Decreto 20/2002- ${ }^{180}$. Además, en Andalucía, debe mencionarse la publicidad institucional impulsada desde el Centro de Turismo de Interior de Andalucía (Centia), como son catálogos, guías y directorios, y la integración en circuitos y centrales de reservas de la Administración. Ni que decir tiene que no deben ser objeto de promoción como turismo rural los inmuebles explotados en situación clandestina ${ }^{181}$.

Asimismo, es evidente que en esta modalidad turística, en la que el usuario no permanece estático en un establecimiento sino que recorre el conjunto de la comarca, es fundamental la existencia de una adecuada señalización turística. A este respecto, aun cuando no debe ignorarse la importante labor de promoción turística desarrollada por la Administración ambiental en los Municipios ubicados en los parques naturales de Andalucía -mediante los centros de recepción e interpretación de los parques naturales, la señalización de senderos, miradores, áreas recreativas...-, se sigue echando en falta una acción más decidida por parte de la Administración turística, que supere las deficiencias, ya indicadas en el Plan Senda y que aún persisten en este ámbito -au-

${ }^{179}$ Decreto de Extremadura 120/1998 -art. 27-. Por su parte, el Decreto de Galicia 191/2004 -art. 63- declara que los establecimientos beneficiarios de subvenciones de la Administración turística quedan automáticamente adscritos a la Central de Reservas de Alojamiento de Turismo Rural de la "Sociedad de Imagen y Promoción Turística de Galicia S.A."

${ }^{180}$ Como se ha señalado, por Orden de 19 de septiembre de 2003 se aprobaron los distintivos de los alojamientos turísticos en el medio rural y de los mesones rurales.

181 Así lo establece de modo expreso el Decreto de Canarias 18/1998 -art. 20-. 
sencia de homogeneidad, escasa calidad técnica...-. Y, además, se observa una cierta descoordinación entre la promoción efectuada por la Administración ambiental de la Red de Parques Naturales Andaluces (RENPA) y la impulsada por la Administración turística.

Igualmente, parece mejorable la coordinación de las actuaciones de promoción de la Administración turística andaluza y la Administración competente en la conservación y gestión del patrimonio cultural, uno de los recursos turísticos claves en la conformación de una identidad propia del turismo rural, en especial en relación con los bienes que se consideren de especial interés turístico ${ }^{182}$.

En relación con las Entidades Locales, no deben desconocerse las actividades de promoción que vienen ejerciendo las Diputaciones Provinciales ${ }^{183}$. De hecho, sigue vigente el diagnóstico del Plan Senda, según el cual el conjunto de la Andalucía rural como destino turístico es más bien la yuxtaposición de destinos provinciales e incluso comarcales, cada uno de los cuales se esfuerza por ofrecer al mercado sus especificidades ${ }^{184}$. A este respecto, el Decreto 20/2002 -art. 6.2- indica que la Administración autonómica fomentará, entre otras medidas, la integración de las Entidades Locales en el proceso de cualificación de los recursos turísticos, las iniciativas turísticas conjuntas generadas por Entidades Locales agrupadas, así como la complementación de las acciones promocionales de las Entidades Locales dentro del marco de la imagen turística de Andalucía como destino turístico integral ${ }^{185}$.

182 El Plan Senda ya enunció una serie de líneas de actuación plenamente vigentes, caso de la confección conjunta de una inventario del patrimonio cultural rural de especial valor turístico, que tendría por objeto seleccionar aquellos bienes de interés cultural presentes en el medio rural que realmente puedan ser utilizables desde el punto de vista de su aprovechamiento turístico.

${ }^{183}$ Debe recordarse que la Ley 11/1987, de 26 de diciembre, reguladora de las Relaciones entre la Comunidad Autónoma de Andalucía y las Diputaciones Provinciales de su Territorio, establece que las Diputaciones Provinciales, como competencia propia -no delegada- en materia de turismo, podrán promocionar los recursos, zonas o fiestas de especial interés para la provincia. Precepto que ha venido a reproducir el art. 4.2 de la Ley 12/1999. Asimismo, no puede desconocerse la competencia atribuida a las Diputaciones Provinciales por la Ley 57/2003 de reforma de la LRBRL, en materia de cooperación en el fomento del desarrollo económico y social.

${ }^{184}$ Recientemente, la Diputación de Jaén ha anunciado la creación de un distintivo propio de calidad de turismo (Jaén Calidad, turismo con denominación de origen) para promocionar la oferta turística de la provincia. El País, 27-5-2005.

185 Se trata de una práctica reproducción del art. 4.1.b) de la Ley 12/1999. Debe recordarse que la Ley 12/1999, siguiendo el ejemplo de otras Leyes autonómicas desde la Ley de Canarias -arts. 3 y 53-, dispone que Andalucía en su conjunto se considera como destino turístico integral, con tratamiento unitario en su promoción fuera del territorio. 
Por último, el Decreto 20/2002 -art. 6.1- declara que la Consejería competente en materia de turismo coordinará la labor de promoción de toda la oferta turística en las zonas de Andalucía incluidas en los programas de apoyo de la Unión Europea, y promoverá la coordinación y el diálogo permanente con la Administración del Estado en la promoción exterior de los productos turísticos de Andalucía ${ }^{186}$.

\subsubsection{Fomento del Turismo Rural}

El turismo rural en España ha sido el destinatario de un considerable flujo de financiación pública, especialmente de fondos europeos y de ayudas de las Administraciones autonómicas, fenómeno que no ha estado exento también de problemas de coordinación administrativa. En general, la política de fomento del turismo rural desarrollada desde fechas muy tempranas por las Comunidades Autónomas tiene por finalidad la mejora de la competitividad de las entidades privadas que actúan en el espacio rural, así como el reforzamiento del tejido asociativo y la creación de empresas de turismo en el espacio rural ${ }^{187}$.

Por lo que se refiere en concreto al ordenamiento andaluz, el Decreto 20/2002 -art. 39.1- declara que se podrán otorgar subvenciones para la implantación, adaptación y mejora de los servicios turísticos en el medio rural y del turismo activo, pudiendo establecer líneas específicas dirigidas a mujeres y jóvenes. Asimismo, se fomentará la utilización de las nuevas tecnologías para la gestión individual o agrupada de los servicios turísticos en el medio rural y de turismo activo -art. 39.2-, y el asociacionismo entre empresas que presten servicios turísticos en el medio rural y de turismo activo -art. 40.1-188.

Más en concreto, pueden diferenciarse dos tipos de líneas de ayudas, unas dirigidas a los titulares de los establecimientos turísticos y otras dirigidas a las Entidades Locales. En cuanto a las primeras, la normativa autonómica contempla ayudas para la creación, ampliación, reforma y modernización de los

\footnotetext{
${ }^{186}$ Como es sabido, la STC 125/94, de 20 de diciembre, declaró que la promoción exterior del turismo tiene una dimensión que la sitúa dentro del título estatal relativo al comercio exterior -art. 149.1.10 CE-, si bien dicha sentencia -que se limitó a enjuiciar una disposición estatal- no negó explícitamente una competencia paralela por parte de las Comunidades Autónomas.

${ }^{187}$ Vid. una exposición general en C. SANZ DOMÍNGUEZ, op. cit., pp. 107 y ss.

188 Del empuje del asociacionismo del sector en Andalucía es expresiva la Red Andaluza de Alojamientos Rurales (RAAR).
} 
establecimientos de alojamiento turístico en el medio rural (con excepción de los apartamentos turísticos rurales), esto es casas rurales, establecimientos hoteleros y complejos turísticos rurales -art. 3- ${ }^{189}$. En cambio, las ayudas para las viviendas turísticas de alojamiento rural se contemplan exclusivamente para las reformas para su transformación en algún tipo de establecimiento de alojamiento turístico. Por tanto, es claro el objeto de promover la profesionalización del sector.

Asimismo, se contemplan también ayudas para la creación, reforma y modernización de los Mesones rurales (es decir, establecimientos de restauración el medio rural con gastronomía típica andaluza $)^{190}$. No obstante, se echan en falta disposiciones que obliguen a los titulares de establecimientos de turismo rural beneficiarios de subvenciones de la Administración turística, p. j., a asistir a los cursos de formación o perfeccionamiento que organice el centro directivo correspondiente de la consejería competente en materia de turismo ${ }^{191}$.

Ahora bien, de poco sirve potenciar los establecimientos turísticos en el medio rural si los recursos turísticos de la zona, aunque parezcan modestos, no se señalizan ni se ponen en valor (la cueva del lugar está enrejada para que no se caigan dentro los chiquillos, la ermita es utilizada de recinto para un rebaño de cabras, la fuente de aguas freáticas está inaccesible en una finca privada... $\left.{ }^{192}\right)$. Así, deben señalarse las líneas de ayuda dirigidas a las Entidades

189 Orden de 28 de enero de 2004, por la que se regula el procedimiento general para la concesión de subvenciones en materia de infraestructura turística, y en términos similares la posterior Orden de 8 de marzo de 2005 por la que se establecen las bases reguladoras para la concesión de subvenciones a empresas privadas en materia de turismo. Según la Orden -art. 5-, se concede prioridad al acondicionamiento de conjuntos arquitectónicos singulares para su aprovechamiento turístico y la reforma y acondicionamiento de edificaciones tradicionales para su integración en la oferta reglada; así como a las solicitudes dirigidas a la implantación de tecnologías y sistema de organización relativos a la mejora de los sistemas de gestión, el mejor uso y depuración de aguas, gestión energética, generación y tratamiento de residuos y contaminación acústica; las actuaciones necesarias para incrementar la categoría del establecimiento, y las dirigidas a incrementar la accesibilidad y reserva de espacios para discapacitados así como los accesos en general.

190 Orden de 28 de enero de 2004 y posterior Orden de 8 de marzo de 2005 -art. 5-. Ya le Plan Senda señaló la necesidad de intensificar las ayudas públicas para la creación de una oferta de restauración en el medio rural, priorizando aspectos como la integración en el entorno, la tipología edificatoria, mobiliario, decoración, vajilla..., así como la incorporación de la gastronomía tradicional a la carta ofrecida.

191 Así el Decreto de Galicia 191/2004 -art. 64-.

192 Se trata de ejemplos reales de un municipio de la Sierra Norte de Sevilla. 
Locales que tienen por objeto infraestructuras turísticas, tales como señalización de recursos turísticos, embellecimiento de accesos a los elementos turísticos, establecimientos de oficinas o puntos de información turística, creación o adecuación de senderos, de áreas recreativas, miradores, paneles informativos, entre otros ${ }^{193}$.

De otro lado, deben tenerse en cuenta las ayudas dirigidas al fomento del desarrollo local, que tienen una trascendencia fundamental en el mundo rural andaluz, tanto por su extensión superficial -abarcando la casi totalidad de los espacios rurales andaluces- como por la magnitud de los recursos económicos movilizados, de los cuales aproximadamente la mitad se relacionan con la actividad turística ${ }^{194}$. Y, en tal sentido, se concede un especial apoyo a aquellos proyectos empresariales calificados como I+E cuando la actividad se oriente, entre otros ámbitos de actuación, a la promoción del turismo rural -art. 22.1-195. Por todo ello, es precisa una mayor coordinación entre los Consorcios de las Unidades Territoriales de Empleo y Desarrollo Local y Tecnológico y la Administración turística, que evite la dispersión de iniciativas públicas inconexas.

Más aún, habida cuenta la común incidencia en la actividad de fomento de otras instancias -Administración ambiental, cultural, de cooperación con los municipios...-, en los casos más significativos podría utilizarse el instrumento previsto en la Ley 12/1999 de Turismo -art. 16- de declaración de Zonas de Preferente Actuación Turística y los consiguientes Planes de Actuación Turística Integrada, en cuya elaboración y aplicación debe potenciarse la participación de las Entidades Locales afectadas. Asimismo, este instrumento prevé la posible formulación de planes de ordenación del territorio de ámbito subregional, que podrían evitar la excesiva concentración de oferta de alojamientos en escasos núcleos frente a la pervivencia de otras áreas en la misma comarca ajenas al desarrollo turístico.

\footnotetext{
193 Orden de la Consejería de Turismo, Comercio y Deporte de 10 de marzo de 2005, por la que se establecen las bases reguladoras para la concesión de subvenciones a Entidades Locales en materia de infraestructura turística.

${ }^{194}$ Por lo que se refiere a Andalucía, en relación con el Programa Operativo PRODER (Desarrollo y Diversificación Económica de las Zonas Rurales) la Comisión Europea aprobó el 29 de diciembre de 2000 el Programa Operativo Integrado de Andalucía, que contiene los ejes prioritarios de desarrollo rural, tanto ligado a actividades agrarias como de diversificación económica de zonas rurales, ordenado mediante Decreto 7/2002, de 15 de enero.

195 Orden de la Consejería de Empleo de 21 de enero de 2004, modificada por Orden de 22 de noviembre de 2004 .
} 


\section{CONCLUSIONES}

En nuestro país, el reparto competencial sobre la materia turística ha derivado en una completa regionalización de la ordenación del turismo rural, en la cual las distintas Comunidades Autónomas tratan de competir entre sí, perfilando un producto turístico con identidad propia. La dispersión de denominaciones y tipologías resultante, en la que una misma calificación -como la de "casa rural"- refiere realidades muy diversas, ha podido ser interesante en una etapa inicial en la que el turismo rural es practicado principalmente por turistas nacionales, pero puede ser un inconveniente para una necesaria apertura hacia mercados exteriores que reduzca la estacionalidad actual de esta modalidad turística, pues deberá competir con las ofertas más homogéneas y con mayor tradición de otros países (caso de Francia). A la vista de las tendencias del modelo autonómico, es previsible que la única forma de hacer frente a este reto requiera de una actuación de homologación por vía de organizaciones privadas de base asociativa.

Asimismo, en la ordenación autonómica del turismo rural se ha producido, en términos generales, una cierta evolución. En una primera etapa, la finalidad principal consistía en diversificar las rentas del mundo rural, de tal modo que se vinculó, de un modo excesivamente rígido, el emplazamiento y el ejercicio de la actividad turística a las explotaciones agrarias y a la dedicación a las mismas. De este modo, la ordenación del turismo rural se configuraba como una actividad auxiliar o secundaria de las actividades agrarias.

En cambio, en una segunda etapa, se hace evidente la estrechez del anterior planteamiento para atender a la demanda creciente por una sociedad urbana de este producto turístico, para lo cual la ordenación se independiza del sector agrario, de tal modo que la finalidad primordial pasa a ser la de garantizar la calidad de la oferta y un cierto grado de seguridad jurídica del cliente, factores determinantes para la consolidación de la demanda, y ello con independencia de quién sea el titular del establecimiento turístico. De este modo, prevalece la perspectiva de explotación de estos alojamientos como actividad empresarial -con la consiguiente quiebra de las exigencias de vecindad o vinculación local del explotador-.

No obstante, las normas autonómicas de esta segunda etapa son aún, en gran medida, disposiciones de corte sectorial, en las que los fines fundamentales son -como se ha dicho- la defensa de la clientela y del producto turístico, principalmente mediante la determinación de unos estándares de calidad de las infraestructuras y servicios turísticos. Pero este planteamiento unidi- 
mensional pasa por alto que lo característico del turismo rural es la integración de valores medioambientales y antropológicos que aún se conservan en el medio rural: la fusión de naturaleza y cultura. Por esta razón, la calidad del turismo rural no se reduce a la calidad del producto estrictamente turístico, sino que se extiende a la calidad del entorno mismo (del paisaje, de los recursos naturales y culturales), cuyo deterioro significaría el estrangulamiento a medio y largo plazo de este producto, al desvalorizar el capital sobre el que se cimenta. Y, por ello, es preciso que la normativa sobre turismo rural incorpore los instrumentos que impulsen un tratamiento más global e integrado de esta actividad.

En nuestra Comunidad Autónoma, tradicionalmente asociada al turismo de sol y playa, se da la circunstancia de que aproximadamente el $19 \%$ de la superficie regional está incluida en alguna figura de protección medioambiental, lo cual constituye una fuerte baza para el desarrollo de esta modalidad turística. Por su parte, la ordenación del turismo rural contenida en el Decreto 20/2002, si bien avanza en la concepción integral de los servicios turísticos en el medio rural, pues no se limita a regular los establecimientos alojativos -a los que incorpora, además, una más amplia tipología- sino que se extiende a otros servicios complementarios -como la restauración y el turismo activo-, sin embargo, mantiene el indicado enfoque unidimensional, pues, salvo referencias perfectamente retóricas, están ausentes en la norma la dimensión natural y cultural del turismo rural.

Asimismo, el Decreto 20/2002 es exponente de la evolución expansiva de la noción de espacio rural: se ha pasado de una noción positiva que vinculaba el espacio rural con aquel en el cual se desarrollan explotaciones agrarias, a una noción predominantemente negativa, esto es como el espacio que no es de litoral ni de ciudad, elementos caracterizados, además, de un modo restrictivo (al limitar el litoral a la franja de 500 metros y considerar rural poblaciones de hasta 20.000 habitantes, cifra muy por encima de la media), y acompañados de una cierta indeterminación normativa (referencia a "núcleos de población").

En cuanto a la configuración normativa de los establecimientos alojativos específicos del turismo rural, se aprecia en el Decreto 20/2002 una clara tendencia a la flexibilización de los rasgos identificadores de este tipo de establecimientos (tamaño reducido, dispersión, trato personalizado...), que tiene importantes manifestaciones, como el incremento de la capacidad alojativa máxima de las casas rurales a 20 plazas -el máximo previsto en el conjunto de la legislación autonómica-, la no imposición de una extensión mínima en el en- 
torno inmediato de las Casas Rurales -ni siquiera para las de categoría superior-, o la falta de imposición de un límite máximo de plazas a los hoteles rurales -en contra de los criterios más extendidos en la legislación autonómica-. Tal vez se ha tenido en mente la conveniencia de aflorar el alto grado de oferta no reglada o paralegal existente en este ámbito, pero no debería olvidarse la necesidad de guardar un equilibrio entre la viabilidad económica del establecimiento y la necesidad de salvaguardar la identidad del producto.

Asimismo, se aprecia también en la configuración de los rasgos definitorios de los tipos alojativos una cierta confusión. En efecto, el aspecto más destacable de la conformación normativa de las casas rurales efectuada por la Ley 12/1999 fue la imposición a estos establecimientos del deber de prestar, además de servicios de alojamiento, "otros servicios complementarios". Este requisito adicional se incluyó con la exclusiva finalidad de diferenciar, en la sistemática de la Ley andaluza, a las casas rurales de las viviendas turísticas de alojamiento rural. Sin embargo, el Decreto 20/2002, apartándose frontalmente de la determinación legal, omite piadosamente dicha exigencia (aún presente en la exposición de motivos de la disposición), de tal modo que la diferencia entre casa rural no compartida y vivienda turística de alojamiento rural aparece ya como un artificio. Además, también sorprende la exigencia a los Hoteles rurales de una oferta de actividades complementarias de ocio y tiempo libre, no contenida, en cambio, para los complejos turísticos rurales, cuando es justamente su elemento característico en el sector. Y, por el contrario, a los Hoteles rurales no se les exige una oferta de gastronómica local, exigencia ésta sí prevista, en cambio, para los complejos turísticos rurales.

De otro lado, planea sobre el contenido del Decreto 20/2002 un criterio de intervencionismo mínimo en la libertad de empresa, pues no sólo están ausentes las exigencias, comunes en la legislación autonómica, relativas al titular del establecimiento, algunas discutibles -como la residencia o arraigo en el medio rural o el aseguramiento de la responsabilidad civil-, y otras más deseables -como la cualificación-, sino que también se inhibe el Decreto en las principales exigencias relativas a la explotación del establecimiento -períodos mínimos de apertura, duración máxima de estancia...-. Asimismo, la Ley 12/1999 optó, con carácter general, por sustituir a la autorización previa por la preceptiva inscripción en el Registro, en principio para aparentar un menor intervencionismo administrativo. Sin embargo, dado el carácter constitutivo de la inscripción -pues constituye título habilitante para el ejercicio lícito de la actividad-, aquella viene a funcionar, materialmente, como una autorización previa, a la que, además, se aplica un silencio desestimatorio, en contra del criterio más extendido en el sector. 
Por último, debido al indicado carácter integral del turismo rural, en la conformación del mismo como producto turístico, y en el consiguiente proceso de satisfacción del turista, intervienen un elevado número de factores, muchos de los cuales superan el limitado marco de actuación de las propias empresas turísticas o el ámbito competencial estricto de la Administración turística, alcanzando a aspectos tan variados como el medio ambiente, el patrimonio cultural o las infraestructuras de obras públicas y transporte. Además, en la actuación sobre el territorio intervienen múltiples organismos -Unidades Territoriales de Empleo y Desarrollo Local y Tecnológico, Juntas Rectoras de los Parques Naturales, Administración cultural... - .

Todo ello reclama de una coordinación adecuada entre la Consejería competente en materia de turismo y los otros Departamentos más directamente implicados -Consejerías competentes en materia de medio ambiente, cultura, ordenación del territorio, agricultura y desarrollo local, principalmente-, así como con las Corporaciones Locales, que, de un lado, contribuya a la necesaria coherencia de la política de turismo rural con el resto de la políticas públicas -políticas de ordenación del territorio, de uso público de los espacios naturales y de los bienes culturales, de desarrollo local...-, y, de otro lado, evite la dispersión de iniciativas públicas inconexas y la disgregación de esfuerzos -sobre todo en materia de promoción y fomento del turismo rural-, utilizando, en su caso, el instrumento previsto en la Ley 12/1999 de Turismo de declaración de Zonas de Preferente Actuación Turística. 